\title{
Chemical Forms of Mercury in Pilot Whales Determined from Species-Averaged Mercury Isotope Signatures
}

\begin{abstract}
Alain Manceau ${ }^{1, *}$, Romain Brossier ${ }^{1, *}$, and Brett A. Poulin ${ }^{2}$
${ }^{1}$ Université Grenoble Alpes, ISTerre, CNRS, 38000 Grenoble, France

${ }^{2}$ Department of Environmental Toxicology, University of California Davis, Davis, CA 95616, USA
\end{abstract}

Correspondence: alain.manceau@ univ-grenoble-alpes.fr; romain.brossier@univ-grenoble-alpes.fr

\begin{abstract}
Marine mammals detoxify organic methylmercury (MeHg) as inorganic mercury selenide $(\mathrm{HgSe})$, yet the nature of the reaction intermediate species and the tissue-specific redistribution of $\mathrm{Hg}$ species in the body are unknown. We report that the identity and proportion of the dominant $\mathrm{Hg}$ species in long-finned pilot whale (Globicephala melas) tissues can be obtained from the bulk variation of isotopic values of $\delta^{202} \mathrm{Hg}$ against the extent of demethylation (percentage of total $\mathrm{Hg}$ as $\mathrm{MeHg}$, $\% \mathrm{MeHg}$ ) using an alternating regularized inversion method. Our analysis of isotope data from two previous studies supports that $\mathrm{MeHg}$ is demethylated as a tetraselenolate species $\left(\mathrm{Hg}(\mathrm{Sec})_{4}\right)$, which further transforms into $\mathrm{HgSe} . \mathrm{Hg}(\mathrm{Sec})_{4}$ occurs in the liver, kidneys, muscle, heart, and brain, whereas HgSe biomineralization occurs only in the liver and kidneys. This study provides a mathematical approach that facilitates probing the molecular-level chemistry of mercury in biological tissues using bulk isotopic data.
\end{abstract}

Keywords: Mercury, demethylation, isotope fractionation, whale, inversion 


\section{INTRODUCTION}

The enrichment of the biosphere in anthropogenic mercury $(\mathrm{Hg})$ impacts wildlife and humans across the globe. ${ }^{1-4}$ Despite detailed understanding of the environmental conditions that promote the uptake of neurotoxic methylmercury $(\mathrm{MeHg})$ in food webs, key knowledge gaps remain on the internal transformations, redistribution, and toxicologic mechanisms of $\mathrm{Hg}$ in higher organisms. Recently, advancement in the application of high energy-resolution X-ray absorption (HR-XANES) spectroscopy in wildlife identified that $\mathrm{MeHg}$ is detoxified to nontoxic mercury selenide $(\mathrm{HgSe})$ through an intermediary Hg-tetraselenolate $\left(\mathrm{Hg}(\mathrm{Sec})_{4}\right)$ species $^{5-7}$ The step-wise transformation of $\mathrm{MeHg}$ observed in bird and fish tissues $\left(\mathrm{MeHg} \rightarrow \mathrm{Hg}(\mathrm{Sec})_{4} \rightarrow \mathrm{HgSe}\right)$, likely initiated by selenoprotein $\mathrm{P}(\mathrm{SelP}){ }^{5}$ provided the first in vivo mechanistic information for the observation of $\mathrm{HgSe}$ in the liver and extrahepatic tissues of marine mammals ${ }^{8-12}$ and seabirds ${ }^{6}$ using standard resolution X-ray absorption spectroscopy and electron microscopy. Although these two techniques provide critical structural information on mercury, ${ }^{8-26}$ they provide limited insight into biochemical processes essential for understanding the toxicokinetics of toxic MeHg in organisms (i.e., fate, tissue-specific exchange).

Stable isotope ratios of $\mathrm{Hg}$ offer a powerful alternative to spectroscopic and microscopic approaches. ${ }^{27}$ Chemical reactions induce a fractionation of isotopes between reactants and products, ${ }^{28-}$ 34 and therefore $\mathrm{Hg}$ metabolic pathways can be investigated if species-specific stable isotope signatures are known. ${ }^{35,36}$ The isotopic fractionation of ${ }^{202} \mathrm{Hg}$ relative to ${ }^{198} \mathrm{Hg}$ (denoted as $\delta^{202} \mathrm{Hg}$ ) is well suited for this purpose because $\delta^{202} \mathrm{Hg}$ can vary by more than $3.5 \%$ in biological tissues. ${ }^{30}$ However, tissues usually contain more than one $\mathrm{Hg}$ species, ${ }^{5,6}$ thus bulk $\delta^{202} \mathrm{Hg}$ values are weighted averages of all $\delta^{202} \mathrm{Sp}_{i}$ values present in the tissue

$$
\delta^{202} \mathrm{Hg}_{t}=\sum f\left(\mathrm{Sp}_{i, t}\right) \times \delta^{202} \mathrm{Sp}_{i}
$$


where $i$ is the number of species and $f\left(\mathrm{Sp}_{i, t}\right)$ is the molar fraction of species $i$ in tissue $t$. At present, a key limitation in the field of $\mathrm{Hg}$ toxicology is resolving the linkages between the speciation of $\mathrm{Hg}$ and bulk $\delta^{202} \mathrm{Hg}$ values.

The first attempt to combine HR-XANES spectroscopy and ${ }^{202} \mathrm{Hg}$ fractionation was performed recently by Poulin et al. ${ }^{37}$ on piscivorous birds from lacustrine, estuarine, and marine environments. The demethylation of $\mathrm{MeHg}$ to $\mathrm{Hg}(\mathrm{Sec})_{4}$ led to a $\delta^{202} \mathrm{Hg}(\mathrm{Sec})_{4}-\delta^{202} \mathrm{MeHg}=-2.2 \pm 0.1 \%$ depletion of the

${ }^{202} \mathrm{Hg}$ isotope. Here, we follow a different approach and show that the isotopic signature and proportion of unique $\mathrm{Hg}$ species $\left(\delta^{202} \mathrm{Sp}_{i}\right.$ and $\left.f\left(\mathrm{Sp}_{i, t}\right)\right)$ can be obtained directly from bulk $\delta^{202} \mathrm{Hg}_{t}$ values of tissues and the molar fraction of $\mathrm{MeHg}$ to total $\mathrm{Hg}(f(\mathrm{MeHg}))$, the latter being a routine chemical measurement. The demonstration is performed on two independent data sets on long-finned pilot whale (Globicephala melas) tissues documented by Li et al. $(2020)^{36}$ and Bolea-Fernandez et al. $(2019)^{38}$. The speciation of $\mathrm{Hg}$ as $\mathrm{MeHg}, \mathrm{Hg}(\mathrm{Sec})_{4}$, and $\mathrm{HgSe}$ in long-finned pilot whale tissues were obtained by calculating iteratively the isotopic signature and proportion of unique $\mathrm{Hg}$ species $\left(\delta^{202} \mathrm{Sp}_{i}\right.$ and $\left.f\left(\mathrm{Sp}_{i, t}\right)\right)$ using a regularized inversion method. ${ }^{39,40}$ The mathematical approach showcases how $\mathrm{Hg}$ speciation data can be obtained from bulk isotopic ratios, providing a new tool to investigate the transformations and tissuespecific redistribution of the $\mathrm{Hg}$ species in organisms.

\section{METHODS}

Data. The $\delta^{202} \mathrm{Hg}_{t},[\mathrm{Hg}]_{\mathrm{tot}}$, total Se ([Se] $\left.]_{\mathrm{tot}}\right)$, and $f(\mathrm{MeHg})$ data from Li et al. $(2020)^{36}$ included data of the liver, kidneys, muscle, heart, and brain of 3 juvenile and 4 adult long-finned pilot whales ( $G$. melas) sampled in the Faroe Islands (2016) $(n=35)$. The $\delta^{202} \mathrm{Hg}_{t},[\mathrm{Hg}]_{\text {tot, }}$ and $f(\mathrm{MeHg})$ data from BoleaFernandez et al. (2019) $)^{38}$ included data of the liver, kidneys, and muscle tissues of juvenile $(n=10,10$, and 8 , respectively) and adult $(n=11,10$, and 6 , respectively) long-finned pilot whales (G. melas). Bolea-Fernandez et al. (2019) ${ }^{38}$ also measured $\delta^{202} \mathrm{Hg}_{t}$ in the blood of 7 juvenile and 7 adult pilot whales, 
but not $f(\mathrm{MeHg})$. The whales were stranded on a Scottish beach in the United Kingdom (September 12, 2012). For liver tissues of Bolea-Fernandez et al. $(2019)^{38}$, [Se $]_{\text {tot }}$ data were obtained from Gajdosechova et al. (2016). ${ }^{12}$ Wet weight $[\mathrm{Hg}]_{\text {tot }}$ and $[\mathrm{Se}]_{\text {tot }}$ of Bolea-Fernandez et al. $(2019)^{38}$ were converted to dry weight values using the average moisture content of $73.8 \pm 2.8 \%$ determined by Li et al. (2020) for similar tissues. $^{36}$

Analysis of Hg:Se Ratio: The ratio of $\mathrm{Hg}$ to Se was evaluated using the approach outline in Manceau et al. (2021). ${ }^{6}$ Briefly, the molar ratio of $\mathrm{Hg}$ to $\mathrm{Se}\left(\mathrm{Hg}: \mathrm{Se}_{\text {chem }}\right)$ was determined using chemical measurements. To account for the stoichiometry of the $\mathrm{Hg}(\mathrm{Sec})_{4}$ and $\mathrm{HgSe}$ species observed in the whale tissues, the effective $\mathrm{Hg}: \mathrm{Se}\left(\mathrm{Hg}: \mathrm{Se}_{\mathrm{eff}}\right)$ was determined (Eq. 2) using values of $f(\mathrm{HgSe})$ and $f\left(\mathrm{Hg}(\mathrm{Sec})_{4}\right)$ determined by alternating regularization.

$$
\mathrm{Hg}: \mathrm{Se}_{\text {eff }}=\mathrm{Hg}: \mathrm{Se}_{\mathrm{chem}} \times\left(f(\mathrm{HgSe})+4 \times f\left(\mathrm{Hg}(\mathrm{Sec})_{4}\right)\right)
$$

\section{RESULTS AND DISCUSSION}

The species distribution of $\mathrm{Hg}$ as $\mathrm{MeHg}, \mathrm{Hg}(\mathrm{Sec})_{4}$, and $\mathrm{HgSe}$ in pilot whale tissues was obtained by calculating iteratively $\delta^{202} \mathrm{Sp}_{i}$ and $f\left(\mathrm{Sp}_{i, t}\right)$ in three steps: (1) an initialization of $\delta^{202} \mathrm{Sp}_{i}$ for each of the three $\mathrm{Hg}$ species using the published $\delta^{202} \mathrm{Hg}_{t}$ versus $f(\mathrm{MeHg})$ data, ${ }^{36,38}$ (2) an estimation of the fractional amounts of $\mathrm{Hg}(\mathrm{Sec})_{4}\left(f\left(\mathrm{Hg}(\mathrm{Sec})_{4}\right)\right)$ and $\mathrm{HgSe}(f(\mathrm{HgSe}))$ using fixed $\delta^{202} \mathrm{Sp}_{i}$ values and measured $\delta^{202} \mathrm{Hg}_{t}$ and $f(\mathrm{MeHg})$ values, and (3) an inverse calculation ${ }^{41}$ of $\delta^{202} \mathrm{Sp}_{i}$ with fixed $f\left(\mathrm{Hg}(\mathrm{Sec})_{4}\right)$ and $f(\mathrm{HgSe})$ values and measured $\delta^{202} \mathrm{Hg}_{t}$ and $f(\mathrm{MeHg})$ values. Steps 2 and 3 are repeated with new values of $f\left(\mathrm{Hg}(\mathrm{Sec})_{4}\right), f(\mathrm{HgSe})$, and $\delta^{202} \mathrm{Sp}_{i}$ assigned at every iteration until convergence is reached.

Step 1: Initialization of $\boldsymbol{\delta}^{\mathbf{2 0 2}} \mathbf{S p}_{\boldsymbol{i}}$. The Li et al. $(2020)^{36}$ and Bolea-Fernandez et al. $(2019)^{38}$ data are highly consistent in the trends between bulk $\delta^{202} \mathrm{Hg}_{t}$ and $f(\mathrm{MeHg})$ (Fig. 1a,b). $\delta^{202} \mathrm{Hg}_{t}$ values are highest in the muscle and heart tissues with $f(\mathrm{MeHg}) \approx 1.0$ and decrease linearly with decreasing $f(\mathrm{MeHg})$ in the muscle, heart, and brain tissues. At $f(\mathrm{MeHg}) \leq \sim 0.2$, which is observed exclusively in the liver and 
kidneys of adult pilot whales, $\delta^{202} \mathrm{Hg}_{t}$ rebounds to more positive values. The ranges of $\delta^{202} \mathrm{Hg}_{t} \operatorname{values}$ for the three conditions of $f(\mathrm{MeHg})$ are also similar between the two studies: $\delta^{202} \mathrm{Hg}_{t}=1.0$ to $1.4 \%$ for $f(\mathrm{MeHg}) \approx 1, \delta^{202} \mathrm{Hg}_{t}=-0.4$ to $0.3 \%$ for $f(\mathrm{MeHg}) \approx 0.0$, and $\delta^{202} \mathrm{Hg}_{t}$ exhibits a minimum of $\sim-1.3 \%$ at $f(\mathrm{MeHg}) \approx 0.05$ to 0.10 . Previous measurements show that $\mathrm{MeHg}$ is almost completely demethylated as nanoparticulate $\mathrm{HgSe}$ in the liver of pilot whales, ${ }^{9}, 12$ and therefore the $\delta^{202} \mathrm{Hg}$ value for $\mathrm{HgSe}$ was initialized as $\delta^{202} \mathrm{HgSe}=0.0 \%$. One liver tissue of an adult pilot whale from the Li et al. $(2020)^{36}$ data is an outlier with $\delta^{202} \mathrm{Hg}=0.33 \%$ for $f(\mathrm{MeHg})=0.08$ (black arrow in Fig. 1a). Importantly, the hockey stick shape of the $\delta^{202} \mathrm{Hg}_{t}$ versus $f(\mathrm{MeHg})$ plots (Fig. 1) suggests the occurrence of an intermediate species in the $\mathrm{MeHg} \rightarrow \mathrm{HgSe}$ reaction, which was previously documented to be $\mathrm{Hg}(\mathrm{Sec})_{4}{ }^{5-7}$ The analysis here supports that $\mathrm{Hg}(\mathrm{Sec})_{4}$ is highly enriched in lighter $\mathrm{Hg}$ isotopes compared to $\mathrm{MeHg}$, consistent with the observed MDF of mercury due to the demethylation of $\mathrm{MeHg}$ to $\mathrm{Hg}(\mathrm{Sec})_{4}{ }^{37}$ and to a lesser extent $\mathrm{HgSe}$.

Next, initialized $\delta^{202} \mathrm{Hg}$ values of $\mathrm{MeHg}\left(\delta^{202} \mathrm{MeHg}\right)$ and $\mathrm{Hg}(\mathrm{Sec})_{4}\left(\delta^{202} \mathrm{Hg}(\mathrm{Sec})_{4}\right)$ were obtained by a linear regression of $\delta^{202} \mathrm{Hg}_{t}$ versus $f(\mathrm{MeHg})$ for tissues exempt of $\mathrm{HgSe}$. Fig. 1 shows that the $\delta^{202} \mathrm{Hg}_{t}$ values for muscle, heart, and brain tissues are significantly correlated with $f(\mathrm{MeHg})$, and therefore can be used to estimate $\delta^{202} \mathrm{Hg}(\mathrm{Sec})_{4}$. Furthermore, careful study of the data shows that two kidneys of juvenile pilot whales of Li et al. $(2020)^{36}$ and several liver and kidneys tissues of Bolea-Fernandez et al. (2019) ${ }^{38}$ align with the $\delta^{202} \mathrm{Hg}_{t}$ versus $\mathrm{MeHg}$ regression. Therefore, the initial values of $\delta^{202} \mathrm{Hg}(\mathrm{Sec})_{4}$ were determined by regression of the selected tissues of each data set that provided the highest coefficient of determination between $\delta^{202} \mathrm{Hg}_{t}$ versus $f(\mathrm{MeHg}): R^{2}=0.96$ for the Li et al. (2020) data $(n$ $=23)^{36}$, and $R^{2}=0.97$ for the Bolea-Fernandez et al. $(2019)^{38}$ data $(n=35)$ (Fig. 2 and Tables S1 and $\mathrm{S} 2$ ). The initialized $\delta^{202} \mathrm{Sp}_{i}$ values derived from the two regression lines are $\delta^{202} \mathrm{MeHg}=1.26 \pm 0.01 \%$ and $\delta^{202} \mathrm{Hg}(\mathrm{Sec})_{4}=-1.56 \pm 0.02 \%$ for the Li et al. (2020) data ${ }^{36}$, and $\delta^{202} \mathrm{MeHg}=1.20 \pm 0.01 \%$ and $\delta^{202} \mathrm{Hg}(\mathrm{Sec})_{4}=-1.33 \pm 0.02 \%$ for the Bolea-Fernandez et al. $(2019)^{38}$ data. The regression analyses and 
standard deviations (root mean squared error) accounted for the reported uncertainties of both $\delta^{202} \mathrm{Hg}_{t}$ and $f(\mathrm{MeHg})$ values. The initialized values of $\delta^{202} \mathrm{MeHg}$ and $\delta^{202} \mathrm{Hg}(\mathrm{Sec})_{4}$ are remarkably similar in the two studies.

Step 2: Estimation of $\boldsymbol{f}\left(\mathrm{Hg}(\mathrm{Sec})_{4}\right)$ and $\boldsymbol{f}(\mathbf{H g S e})$. The measured $\delta^{202} \mathrm{Hg}_{t}$ values in the two pilot whale studies are the weighted averages of the three species-specific $\delta^{202} \mathrm{MeHg}, \delta^{202} \mathrm{Hg}(\mathrm{Sec})_{4}$, and $\delta^{202} \mathrm{HgSe}$ values. Therefore, the fractional amounts of $\mathrm{Hg}(\mathrm{Sec})_{4}$ and $\mathrm{HgSe}$ in each tissue can be calculated from Equations 3 and 4.

$$
\begin{gathered}
\left(f(\mathrm{MeHg}) \times \delta^{202} \mathrm{MeHg}\right)+\left(f\left(\mathrm{Hg}(\mathrm{Sec})_{4}\right) \times \delta^{202} \mathrm{Hg}(\mathrm{Sec})_{4}\right)+\left(f(\mathrm{HgSe}) \times \delta^{202} \mathrm{HgSe}\right)=\delta^{202} \mathrm{Hg}_{t} \\
f(\mathrm{MeHg})+f\left(\mathrm{Hg}(\mathrm{Sec})_{4}\right)+f(\mathrm{HgSe})=1
\end{gathered}
$$

$f(\mathrm{MeHg})$ is known from chemical measurement. $f\left(\mathrm{Hg}(\mathrm{Sec})_{4}\right)$ and $f(\mathrm{HgSe})$ were estimated using the initialized $\delta^{202} \mathrm{MeHg}$ and $\delta^{202} \mathrm{Hg}(\mathrm{Sec})_{4}$ values obtained from the linear regressions (Fig. 2) and $\delta^{202} \mathrm{HgSe}$ $=0.00 \%$ (Step 1). The estimated values of $f\left(\mathrm{Hg}(\mathrm{Sec})_{4}\right)$ decreases linearly with increasing $f(\mathrm{HgSe})$ in the liver of adult pilot whales in both studies $\left(\mathrm{R}^{2}=0.99\right.$, Fig. S1a), which is the tissue with the lowest amounts of MeHg. This result confirms that the tissues behave as a ternary system and further supports the interpretation that $\mathrm{Hg}(\mathrm{Sec})_{4}$ is the precursor to nanoparticulate $\mathrm{HgSe}^{5,6} f\left(\mathrm{Hg}(\mathrm{Sec})_{4}\right)$ and $f(\mathrm{HgSe})$ also covary negatively in the kidneys of adult pilot whales and in the livers of juveniles (Fig. S1a), but the coefficient of determination between $f\left(\mathrm{Hg}(\mathrm{Sec})_{4}\right)$ and $f(\mathrm{HgSe})$ is lower if these tissues are included because they contain more $\mathrm{MeHg}$ than the livers of adult whales. The liver tissue of the Li et al. $(2020)^{36}$ study that was an outlier (Fig. 1a) is not presented in Figure S1a, as the estimated $f\left(\operatorname{Hg}(\operatorname{Sec})_{4}\right)$ and $f(\mathrm{HgSe})$ were outside the feasible range $\left(f\left(\mathrm{Hg}(\mathrm{Sec})_{4}\right)=-0.18, f(\mathrm{HgSe})=1.07\right)$.

Step 3: Calculation of $\delta^{202} \mathrm{Sp}_{i}, f\left(\mathrm{Hg}(\mathrm{Sec})_{4}\right)$, and $f(\mathrm{HgSe})$ by alternating regularized inversion. Eq. 3 can be written in a matrix format 


$$
\underbrace{\left[\begin{array}{l}
f\left(\mathrm{MeHg}_{1}\right) f\left(\operatorname{Hg}(\mathrm{Sec})_{4,1}\right) f\left(\mathrm{HgSe}_{1}\right) \\
f\left(\mathrm{MeHg}_{2}\right) f\left(\operatorname{Hg}(\mathrm{Sec})_{4,2}\right) f\left(\mathrm{HgSe}_{2}\right) \\
\cdots \\
f\left(\mathrm{MeHg}_{n}\right) f\left(\operatorname{Hg}(\mathrm{Sec})_{4, n}\right) f\left(\mathrm{HgSe}_{n}\right)
\end{array}\right]}_{\mathbf{A}} \underbrace{\left(\begin{array}{l}
\delta^{202} \mathrm{MeHg} \\
\delta^{202} \mathrm{Hg}(\mathrm{Sec})_{4} \\
\delta^{202} \mathrm{HgSe}
\end{array}\right)}_{\mathbf{X}}=\underbrace{\left(\begin{array}{l}
\delta^{202} \mathrm{Hg}_{1} \\
\delta^{202} \mathrm{Hg}_{2} \\
\cdots \\
\delta^{202} \mathrm{Hg}_{n}
\end{array}\right)}_{\mathbf{b}}
$$

where $n$ is the number of tissue samples. Calculating $\delta^{202} \mathrm{Sp}_{i}$ when $f\left(\mathrm{Sp}_{i, t}\right)$ and $\delta^{202} \mathrm{Hg}_{t}$ are known from speciation measurements (e.g., HR-XANES) and isotopic measurements is a well-posed inverse problem. ${ }^{41}$ The column vector $\mathbf{x}$ is obtained by minimizing the misfit functional $\varphi(\mathbf{x})$, or residual, that quantifies the difference between the predicted (x) and the observed (b) isotopic data

$$
\varphi(\mathbf{x})=\|\mathbf{A} \mathbf{x}-\mathbf{b}\|^{2}=(\mathbf{A} \mathbf{x}-\mathbf{b})^{\mathrm{T}} \mathbf{C}_{d}^{-1}(\mathbf{A} \mathbf{x}-\mathbf{b})
$$

where $(\mathbf{A x}-\mathbf{b})^{\mathrm{T}}$ denotes the transpose of the vector $(\mathbf{A x}-\mathbf{b})$ and $\mathbf{C}_{\mathrm{d}}^{-1}$ is the inverse matrix of the squared standard deviations of the isotopic measurements. Isotopic measurements are independent and therefore the input covariance $\mathbf{C}_{\mathrm{d}}$ matrix is diagonal and contains the measurement uncertainties of $\delta^{202} \mathrm{Hg}_{t}$. The unknown vector $\mathbf{x}$ is obtained at the minimum of the objective functional $\varphi(\mathbf{x})$, which is equivalent to zero its first derivative.

Here, only $f(\mathrm{MeHg})$ and $\delta^{202} \mathrm{Hg}_{t}$ are known and therefore the problem is ill-posed with non-unique mathematical solutions. Notwithstanding, $a$ chemically meaningful solution to $\delta^{202} \mathrm{Sp}_{i}$ and to the tissuespecific proportions of $\mathrm{Hg}(\mathrm{Sec})_{4}$ and $\mathrm{HgSe}$ can be obtained simultaneously by an alternating regularized inversion method. ${ }^{40}$ The approach necessitates addition of a regularization term to the objective function.

$$
\varphi(\mathbf{x})=\|\mathbf{A} \mathbf{x}-\mathbf{b}\|^{2}=(\mathbf{A} \mathbf{x}-\mathbf{b})^{\mathrm{T}} \mathbf{C}_{\mathrm{d}}^{-1}(\mathbf{A} \mathbf{x}-\mathbf{b})+\lambda \mathbf{x}^{\mathrm{T}} \mathbf{x}
$$

The regularization term $\mathbf{x}^{\mathrm{T}} \mathbf{x}$ allows one to penalize large (i.e., meaningless) values in $\mathbf{x}$ and is weighted by the user-defined $\lambda$ parameter. The weighting parameter $\lambda$ was determined using the so-called $L$-curve criterion defined as 


$$
\lambda=0.01 \times \max \left(\mathbf{A}^{\mathrm{T}} \mathbf{C}_{\mathrm{d}}^{-1} \mathbf{A}\right)
$$

for both the Li et al. (2020) ${ }^{36}$ and the Bolea-Fernandez et al. $(2019)^{38}$ data sets, which is a reasonable value for inverse problems. ${ }^{42}$ Using the notation in Eq. 7, the optimal $\mathbf{x}$ value, as obtained by zeroing the first derivative of the objective function, is

$$
\mathbf{x}=\left[\mathbf{A}^{\mathrm{T}} \mathbf{C}_{\mathrm{d}}^{-1} \mathbf{A}+\lambda \mathbf{I}\right]^{-1} \mathbf{A}^{\mathrm{T}} \mathbf{C}_{\mathrm{d}}^{-1} \mathbf{b}
$$

where $\mathbf{I}$ is the identity matrix.

The workflow schematic for the inversion calculations is presented in Fig. 3 and the Python code is available in the Supporting Information and has been deposited in the GRICAD GitLab's site. ${ }^{43}$ First, the inversion scheme starts with an a priori estimate of $\delta^{202} \mathrm{Sp}_{i}$ (initialization Step 1 described above), in which $\delta^{202} \mathrm{MeHg}$ and $\delta^{202} \mathrm{Hg}(\mathrm{Sec})_{4}$ are the values obtained from the $\delta^{202} \mathrm{Hg}_{t}$ versus $f(\mathrm{MeHg})$ regression (Fig. 2) and $\delta^{202} \mathrm{HgSe}$ is set to $0 \%$. Second, a two-step alternating reconstruction is performed, in which $f\left(\mathrm{Hg}(\mathrm{Sec})_{4}\right)$ and $f(\mathrm{HgSe})$ are obtained from Eq. 3 and 4 using the preset $\delta^{202} \mathrm{Sp}_{i}$ values (Step 2), and $\delta^{202} \mathrm{Sp}_{i}$ is calculated next from Eq. 9 using the previously calculated $f\left(\mathrm{Hg}(\mathrm{Sec})_{4}\right)$ and $f(\mathrm{HgSe})$ values (Step 3). The two variable sets are updated alternatively at each step of the leap-frog process until $\varphi(\mathbf{x})$ converges to a minimum.

The linear system in Step 2 is well-posed and always provides a unique solution. However, $f\left(\mathrm{Hg}(\mathrm{Sec})_{4}\right)$ and $f(\mathrm{HgSe})$ may be negative or $>1$ if the a priori ${ }^{202} \mathrm{Sp}_{i}$ values are unrealistic. When this is the case, the algorithm automatically projects the unacceptable fractions onto a user-defined admissible range. In the pilot whale data analyzed here, it was observed that a small negative value of $f\left(\mathrm{Hg}(\mathrm{Sec})_{4}\right)$ and $f(\mathrm{HgSe})$ equal to the uncertainty of the known $f(\mathrm{MeHg})$ value (e.g., \pm 0.05$)$ did not prevent global convergence. The number of iterations in the inner loop increased from 513 to 533 for the Li et al. (2020) data, ${ }^{36}$ and from 231 to 237 for the Bolea-Fernandez et al. (2019) data, ${ }^{38}$ when the criterion of the upper and lower limits for $f\left(\mathrm{Hg}(\mathrm{Sec})_{4}\right)$ and $f(\mathrm{HgSe})$ was changed from \pm 0.01 to \pm 0.05 , 
but the optimal $\delta^{202} \mathrm{Sp}_{i}, f\left(\mathrm{Hg}(\mathrm{Sec})_{4}\right)$, and $f(\mathrm{HgSe})$ values were identical with the two criteria. The reliability of the iterative method was also evaluated by varying the initial estimate of $\delta^{202} \mathrm{HgSe}$. The reconstruction algorithm converged to the same solution when the initial $\delta^{202} \mathrm{HgSe}$ values for the Li et al. $(2020)^{36}$ and the Bolea-Fernandez et al. $(2019)^{38}$ data sets were set to the experimental value of the liver tissue containing the lowest proportion of $\mathrm{MeHg}\left(f(\mathrm{MeHg})=0.043, \delta^{202} \mathrm{HgSe}=-0.32 \%\right.$ and $f(\mathrm{MeHg})=0.009, \delta^{202} \mathrm{HgSe}=-0.35 \%$, respectively, Tables S1 and S2).

The optimal solutions are $\delta^{202} \mathrm{MeHg}=1.23 \%$, $\delta^{202} \mathrm{Hg}(\mathrm{Sec})_{4}=-1.46 \%$, $\delta^{202} \mathrm{HgSe}=0.00 \%$ for the Li et al. $(2020)^{36}$ data, and $\delta^{202} \mathrm{MeHg}=1.17 \%$ o, $\delta^{202} \mathrm{Hg}(\mathrm{Sec})_{4}=-1.29 \%$, $\delta^{202} \mathrm{HgSe}=0.00 \%$ for the BoleaFernandez et al. (2019) $)^{38}$ data. The $\delta^{202} \mathrm{MeHg}$ and $\delta^{202} \mathrm{Hg}(\mathrm{Sec})_{4}$ values are in good agreement with those derived from the regression analysis in the initialization step; $1.26 \%$ and $1.20 \%$ for $\delta^{202} \mathrm{MeHg}$ and 1.56\% and $-1.33 \%$ or for $\delta^{202} \mathrm{Hg}(\mathrm{Sec})_{4}$ for the Li et al. $(2020)^{36}$ data and Bolea-Fernandez et al. $(2019)^{38}$ data, respectively. The alternating inversion method quantifies $\delta^{202} \mathrm{HgSe}$, whereas the $\delta^{202} \mathrm{Hg}_{t}$ versus $f(\mathrm{MeHg})$ analysis (Step 1) only provides an estimate of $\delta^{202} \mathrm{HgSe}$. Formal uncertainties cannot be calculated on species-specific $\delta^{202} \mathrm{Hg}$ values because the alternating inversion scheme is in essence nonlinear and due to the regularization term $\left(\lambda \mathbf{x}^{\mathrm{T}} \mathbf{x}\right)$. To estimate accuracy of the alternating inversion method, the $\delta^{202} \mathrm{Sp}_{i}$ values were calculated using the two independent data sets together $(n=89)$ and compared with the results presented above on each data set. Analyzed together, the $\delta^{202} \mathrm{Sp}_{i}$ values $\left(\delta^{202} \mathrm{MeHg}=1.21 \%\right.$ o, $\delta^{202} \mathrm{Hg}(\mathrm{Sec})_{4}=-1.37 \%$, and $\delta^{202} \mathrm{HgSe}=0.00 \%$ o $)$ quantify that the uncertainty in the calculated $\delta^{202} \mathrm{Sp}_{i}$ values is $<0.1 \%$.

Proportions of the $\mathrm{Hg}$ species in pilot whale tissues. The proportions of $\mathrm{MeHg}, \mathrm{Hg}(\mathrm{Sec})_{4}$, and $\operatorname{HgSe}\left(f\left(\mathrm{Sp}_{i}\right)\right)$ in long-finned pilot whale tissues of Li et al. $(2020)^{36}(n=34)$ and Bolea-Fernandez et al. $(2019)^{38}(n=55)$ are reported in Tables S1 and S2 and presented graphically in Figure 4. The sum of the proportions of $\mathrm{Hg}$ species being normalized to 1 (Eq. 4), the $f\left(\mathrm{Sp}_{i}\right)$ values define a hyperplane within the three-dimensional $f(\mathrm{MeHg}), f\left(\mathrm{Hg}(\mathrm{Sec})_{4}\right), f(\mathrm{HgSe})$ space. The $f\left(\mathrm{Sp}_{i}\right)$ values are distributed in the 
hyperplane within an equilateral triangle with one $\mathrm{Hg}$ species at each vertice. The two triangles obtained with the Li et al. (2020) $)^{36}$ and the Bolea-Fernandez et al. (2019) ${ }^{38}$ data sets are represented in a threedimensional space in Figure 4a with $\delta^{202} \mathrm{Hg}_{t}$ as the third dimension. The two triangles are practically superimposed in this space, which confirms the high consistency between the two independent data sets.

A two-dimensional projection of the two $f\left(\mathrm{Sp}_{i}\right)$ ternary diagrams is shown in Figure $4 \mathrm{~b}$. Tissues of the pilot whales organize into three classes based on mercury species distribution. First, in the heart and muscle tissues of juvenile and adult whales, mercury is primarily present as $\mathrm{MeHg}$ with a low fraction as $\mathrm{Hg}(\mathrm{Sec})_{4}$ and no $\mathrm{HgSe}$. Second, in the brain of both juvenile and adult whales and most juvenile kidneys tissues, mercury is present as a mixture of $\mathrm{MeHg}$ and $\mathrm{Hg}(\mathrm{Sec})_{4}$. Third, in adult kidneys and both juvenile and adult liver tissues, mercury is present as minor $\mathrm{MeHg}$ and a mixture of both $\mathrm{Hg}(\mathrm{Sec})_{4}$ and $\mathrm{HgSe}$. When evaluated in context of the total concentration of mercury $\left([\mathrm{Hg}]_{\mathrm{tot}}\right)$ in tissues, the fluctuations in $f\left(\mathrm{Sp}_{i}\right)$ with increasing $[\mathrm{Hg}]_{\text {tot }}$ document the step-wise $\mathrm{MeHg} \rightarrow \mathrm{Hg}(\mathrm{Sec})_{4} \rightarrow \mathrm{HgSe}$ demethylation reaction (Fig. 5a-5c). $f(\mathrm{MeHg})$ decreases and $f(\mathrm{HgSe})$ increases with the extent of the reaction, which progresses with $[\mathrm{Hg}]_{\text {tot, }}$ and $f\left(\mathrm{Hg}(\mathrm{Sec})_{4}\right)$ exhibits a unimodal behavior reflecting the intermediate species of the reaction. $f\left(\mathrm{Hg}(\mathrm{Sec})_{4}\right)$ and $f(\mathrm{HgSe})$ covary negatively (Fig. S1b), similar to the observed trend between estimates of $f\left(\mathrm{Hg}(\mathrm{Sec})_{4}\right)$ and $f(\mathrm{HgSe})$ from the initialization step (Step 1, Fig. S1a). The correlation between $f\left(\mathrm{Hg}(\mathrm{Sec})_{4}\right)$ and $f(\mathrm{HgSe})$ reflects the biomineralization of nanoparticulate $\mathrm{HgSe}$ from precursor $\mathrm{Hg}(\mathrm{Sec})_{4} \cdot{ }^{5,6}$ Further, the ratios of $f\left(\mathrm{Sp}_{i}\right)$ values for the $\mathrm{MeHg} \rightarrow$ $\mathrm{Hg}(\mathrm{Sec})_{4}$ reaction $\left(f\left(\mathrm{Hg}(\mathrm{Sec})_{4}\right) / f(\mathrm{MeHg})\right)$ and $\mathrm{Hg}(\mathrm{Sec})_{4} \rightarrow \mathrm{HgSe}$ reaction $\left(f(\mathrm{HgSe}) / f\left(\mathrm{Hg}(\mathrm{Sec})_{4}\right)\right)$ are diagnostic of the extent of the two step reaction (Fig. 5d and 5e). Across all tissues, $f\left(\mathrm{Hg}(\mathrm{Sec})_{4}\right) / f(\mathrm{MeHg})$ is greater in adult compared to juvenile whales for a given tissue and exhibit a hierarchy of heart < muscle < brain < kidneys < liver (Fig. 5d). Similarly, of the tissues with $\mathrm{HgSe}, f(\mathrm{HgSe}) / f\left(\mathrm{Hg}(\mathrm{Sec})_{4}\right)$ is greater in adult compared to juvenile whales and liver compared to kidneys tissues (Fig. 5e). 
The weight concentrations of the three $\mathrm{Hg}$ species are obtained by multiplying $f\left(\mathrm{Sp}_{i}\right)$ by $[\mathrm{Hg}]_{\text {tot }}$ and are presented in Figure 6 for each tissue in ascending order of $[\mathrm{Hg}]_{\text {tot. }}$ Trends in weighted concentrations of the three $\mathrm{Hg}$ species highlight two notable observations. First, the high abundance of $\mathrm{Hg}(\mathrm{Sec})_{4}$ in the brain of juvenile and adult whales, compared to the muscle and heart of similar $[\mathrm{Hg}]_{\text {tot }}$ (Fig. 6a-c), suggests that the brain is better protected against $\mathrm{Hg}$ toxicity than muscular tissues. An evaluation of the ratio of $\mathrm{Hg}$ to $\mathrm{Se}(\mathrm{Hg}: \mathrm{Se} \mathrm{eff})$, accounting for the stoichiometric ratio of $\mathrm{Hg}(\mathrm{Sec})_{4}(1: 4),{ }^{6}$ indicates that the demethylation of $\mathrm{MeHg}$ in the adult whale brain could deplete bioavailable reservoirs of Se $(1.1<$ $\mathrm{Hg}: \mathrm{Se}_{\mathrm{eff}}<3.1$ ) (Tables S1 and S2). It is likely, however, that the brains of adult whales contain polynuclear $\mathrm{Hg}_{\mathrm{x}}(\mathrm{Se}, \mathrm{Sec})_{\mathrm{y}}$ clusters rather than strict mononuclear $\mathrm{Hg}(\mathrm{Sec})_{4}$ complexes, the former observed in waterbird ${ }^{5}$ and seabird ${ }^{6}$ and understood to represent an intermediate in the biomineralization of $\mathrm{HgSe}$ from $\mathrm{Hg}(\mathrm{Sec})_{4} \cdot \mathrm{Hg}_{\mathrm{x}}(\mathrm{Se}, \mathrm{Sec})_{\mathrm{y}}$ clusters have $1<\mathrm{Hg}$ :Se $<4$, therefore omitting this species in the estimation of $\mathrm{Hg}: S e_{\text {eff }}$ underestimates the amount of bioavailable Se. ${ }^{6}$ The possible neurotoxic effects of Se deficiency due to $\mathrm{MeHg}$ demethylation require further study. Second, the primary locations for the detoxification of $\mathrm{MeHg}$ are the liver, kidneys, and brain, and the accumulation of demethylated species $\left(\mathrm{Hg}(\mathrm{Sec})_{4}\right.$ and $\left.\mathrm{HgSe}\right)$ account for $\mathrm{Hg}$ burden in these tissues (Fig. 6). In the kidneys and liver of whales, where the $\mathrm{MeHg} \rightarrow \mathrm{Hg}(\mathrm{Sec})_{4} \rightarrow \mathrm{HgSe}$ demethylation reaction is most advanced, there is no apparent threshold $\mathrm{Hg}$ concentration above which the demethylation of $\mathrm{MeHg}$ into $\mathrm{Hg}(\mathrm{Sec})_{4}$ and $\mathrm{HgSe}$ is initiated. In contrast, a demethylation threshold of approximately $8.5 \mathrm{mg} \mathrm{Hg} / \mathrm{kg}$ dry weight (dw) has been reported in the liver of waterbirds. ${ }^{44}$ This may reflect the greater availability of selenium in marine systems that yield efficient $\mathrm{MeHg} \rightarrow \mathrm{Hg}(\mathrm{Sec})_{4}$ demethylation across broad tissues. ${ }^{36,38}$

To put into context the $\mathrm{Hg}$ speciation results in long-finned pilot whales, a diagrammatic picture of the average concentrations and speciation of $\mathrm{Hg}$ in the tissues of whales juveniles and adults (Fig. S2a,b) are compared to those obtained recently in giant petrel (Macronectes spp) using HR-XANES (Fig. S2c). ${ }^{6}$ Petrels are top predator of food webs and scavengers of mammal and bird carcasses, and therefore 
contain similar amounts of mercury as long-finned pilot whales. In petrel, $\mathrm{HgSe}$ occurs not only in liver and kidneys, but also in brain and muscle. Almost all the $\mathrm{Hg}$ is in the form of $\mathrm{HgSe}$ in liver, and the brain contains $38 \pm 32 \% \mathrm{HgSe}$, despite having less $\mathrm{Hg}(5.9 \pm 6.4 \mathrm{mg} / \mathrm{kg} \mathrm{dw})$ than the whales brains from the Li et al. $(2020)^{36}$ study $(13.8 \pm 7.9 \mathrm{mg} / \mathrm{kg} \mathrm{dw})$. Overall, petrels seem to detoxify MeHg more efficiently than long-finned pilot whales, for reasons yet to be known, making life apparently more compatible with such high contaminant burden.

\section{CONCLUDING REMARKS}

We demonstrated that the atomic-level biochemistry of toxic methylmercury ( $\mathrm{MeHg}$ ) and its degradation products in biological tissues can be obtained by a mathematical treatment of the $\mathrm{Hg}$ isotope data using an iterative regularization method. Inversion methods are used in many fields of science, ${ }^{41}$, ${ }^{45}$ but this is the first application with stable isotopic data. The algorithm, which we developed, was used to probe the internal transformations of mercury in the liver, kidneys, muscle, heart, and brain of long-finned pilot whales. We showed that the hockey stick shape of the $\delta^{202} \mathrm{Hg}_{t}$ versus $f(\mathrm{MeHg})$ graph of whale tissues reflects the step-wise $\mathrm{MeHg} \rightarrow \mathrm{Hg}(\mathrm{Sec})_{4} \rightarrow \mathrm{HgSe}$ reaction and metabolic processes leading to a change of $\mathrm{Hg}$ speciation in and across tissues. The isotopic data can be explained by the coexistence of $\mathrm{MeHg}$ with two inorganic species, $\mathrm{Hg}(\mathrm{Sec})_{4}$ and $\mathrm{HgSe}$, with uniform isotopic signatures: $\delta^{202} \mathrm{MeHg}=1.21 \pm 0.04 \%$, $\delta^{202} \mathrm{Hg}(\mathrm{Sec})_{4}=-1.37 \pm 0.09 \%$, and $\delta^{202} \mathrm{HgSe}=0.00 \pm 0.00 \%$. The $\delta^{202} \mathrm{Hg}(\mathrm{Sec})_{4}-\delta^{202} \mathrm{MeHg}$ difference of $2.58 \pm 0.13 \%$ is similar to that reported recently for birds $(-2.2$ $\pm 0.1 \%)^{37}$

A highlight of this study is the invariance of the three $\delta^{202} \mathrm{Sp}_{i}$ values between the tissues of a same individual, across individuals of the same pod, and between pods sampled at different times in different geographic locations. A similar observation was made previously for the uniformity of $\delta^{202} \mathrm{Hg}$ in the blood of 7 juvenile and 7 adult whales $\left(\delta^{202} \mathrm{Hg}_{\text {blood }}=1.06 \pm 0.05 \%\right.$ o $) .{ }^{38} \mathrm{Li}$ et al. $(2020)^{36}$ interpreted the 
blood results and the linear relationship of $\delta^{202} \mathrm{Hg}$ with $f(\mathrm{MeHg})$ in the heart, brain, and muscle of whales (Fig. 1a,b) to indicate that the isotopic composition of $\mathrm{MeHg}$ is constantly homogenized throughout the body. The isotopic equilibrium of $\mathrm{MeHg}$ reported here agrees with the rapid shifts in $\mathrm{Hg}$ isotope values of fish tissues to values of dietary $\mathrm{MeHg} .{ }^{46}$

We explain the steady state isotopic fractionation of $\mathrm{Hg}(\mathrm{Sec})_{4}$ and $\mathrm{HgSe}$ by (1) a continuous input of isotopically constant $\mathrm{MeHg}$ source from the diet, (2) continuous exchange of $\mathrm{MeHg}$ and $\mathrm{Hg}(\mathrm{Sec})_{4}$ between the circulatory system and tissues, and (3) the rapid turnover of Hg-carrying proteins and elimination of $\mathrm{Hg}$ in urine and feces. The circulation of $\mathrm{Hg}(\mathrm{Sec})_{4}$ in whale blood is supported experimentally by the analysis of Se-containing proteins in the plasma of Inuits, which showed that up to $50 \%$ of $\mathrm{Hg}$ is associated with SelP. ${ }^{47}$ Blood isotopic analysis offers suggestive evidence for the presence of $\mathrm{Hg}(\mathrm{Sec})_{4}$ in the circulatory system. In whales studied by Bolea-Fernandez et al. (2019), ${ }^{38}$ $\delta^{202} \mathrm{Hg}_{\text {blood }}=1.06 \pm 0.05 \%$ o while $\delta^{202} \mathrm{MeHg}$ obtained in all tissues by the alternating regularized inversion is $1.17 \%$. The circulation of $\mathrm{Hg}(\mathrm{Sec})_{4}$ in the blood at $4 \%$ of the total $\mathrm{Hg}$ concentration could account for the $0.11 \%$ difference observed between the $\delta^{202} \mathrm{Hg}_{\text {blood }}$ and $\delta^{202} \mathrm{MeHg}$. In conclusion, this study establishes the possibility to probe the atomic-level chemistry of mercury in animal tissues from species-averaged isotopic data and $f(\mathrm{MeHg})$ alone, without complementary structural information from HR-XANES spectroscopy. This approach will facilitate advancement of the next generation of toxicokinetic models for mercury across diverse organisms.

\section{ASSOCIATED CONTENT}

\section{Supporting Information}

The Supporting Information is available free of charge on the ACS Publications website at DOI:

Supplementary table and figures (PDF)

Python code of the alternating regularized inversion (RegInv-202Hg software) (txt) 
ReadMe of RegInv-202Hg (txt)

Input files of RegInv-202Hg (tx)

Input datasets (txt)

\section{AUTHOR INFORMATION}

\section{Corresponding Author}

E-mail: alain.manceau@univ-grenoble-alpes.fr

\section{ORCID}

Alain Manceau: 0000-0003-0845-611X

Romain Brossier: 0000-0002-7195-8123

Brett A. Poulin: 0000-0002-5555-7733

Notes

The authors declare no competing financial interests.

\section{ACKNOWLEDGMENTS}

Financial support was provided to Brett A. Poulin by the U.S. National Science Foundation under grant EAR-1629698.

\section{REFERENCES}

(1) Douglas, T. A.; Loseto, L. L.; Macdonald, R. W.; Outridge, P.; Dommergue, A.; Poulain, A.; Amyot, M.; Barkay, T.; Berg, T.; Chetelat, J.; Constant, P.; Evans, M.; Ferrari, C.; Gantner, N.; Johnson, M. S.; Kirk, J.; Kroer, N.; Larose, C.; Lean, D.; Nielsen, T. G.; Poissant, L.; Rognerud, S.; Skov, H.; Sorensen, S.; Wang, F. Y.; Wilson, S.; Zdanowicz, C. M. The fate of mercury in Arctic terrestrial and aquatic ecosystems, a review. Environmental Chemistry 2012, 9, 321-355. 
(2) Driscoll, C. T.; Mason, R. P.; Chan, H. M.; Jacob, D. J.; Pirrone, N. Mercury as a global pollutant: Sources, pathways, and effects. Env. Sci. Technol. 2013, 47, 4967-4983.

(3) Lehnherr, I. Methylmercury biogeochemistry: a review with special reference to Arctic aquatic ecosystems. Environ. Rev. 2014, 22, 229-243.

(4) Eagles-Smith, C. A.; Silbergeld, E. K.; Basu, N.; Bustamante, P.; Diaz-Barriga, F.; Hopkins, W. A.; Kidd, K. A.; Nyland, J. F. Modulators of mercury risk to wildlife and humans in the context of rapid global change. Ambio 2018, 47, 170-197.

(5) Manceau, A.; Bourdineaud, J. P.; Oliveira, R. B.; Sarrazin, S. L. F.; Krabbenhoft, D. P.; EaglesSmith, C. A.; Ackerman, J. T.; Stewart, A. R.; Ward-Deitrich, C.; Busto, M. E. D.; Goenaga-Infante, H.; Wack, A.; Retegan, M.; Detlefs, B.; Glatzel, P.; Bustamante, P.; Nagy, K. L.; Poulin, B. A. Demethylation of methylmercury in bird, fish, and earthworm. Environ. Sci. Technol. 2021, 55, 15271534.

(6) Manceau, A.; Gaillot, A. C.; Glatzel, P.; Cherel, Y.; Bustamante, P. In vivo formation of HgSe nanoparticles and Hg-tetraselenolate complex from methylmercury in seabird - Implications for the $\mathrm{Hg}$ Se antagonism. Environ. Sci. Technol. 2021, 55, 1515-1526.

(7) Manceau, A.; Azemard, S.; Hédouin, L.; Vassileva, E.; Lecchini, D.; Fauvelot, C.; Swarzenski, P. W.; Glatzel, P.; Bustamante, P.; Metian, M. The chemical forms of mercury in blue marlin billfish: Implications for human exposure. Environ. Sci.. Technol. Lett. 2021, 8, 405-411.

(8) Arai, T.; Ikemoto, T.; Hokura, A.; Terada, Y.; Kunito, T.; Tanabe, S.; Nakai, I. Chemical forms of mercury and cadmium accumulated in marine mammals and seabirds as determined by XAFS analysis. Environ. Sci. Technol. 2004, 38, 6468-6474.

(9) Nakazawa, E.; Ikemoto, T.; Hokura, A.; Terada, Y.; Kunito, T.; Tanabe, S.; Nakai, I. The presence of mercury selenide in various tissues of the striped dolphin: evidence from $\mu$-XRF-XRD and XAFS analyses. Metallomics 2011, 3, 719-725. 
(10) Lailson-Brito, J.; Cruz, R.; Dorneles, P. R.; Andrade, L.; Azevedo, A. D.; Fragoso, A. B.; Vidal, L. G.; Costa, M. B.; Bisi, T. L.; Almeida, R.; Carvalho, D. P.; Bastos, W. R.; Malm, O. Mercuryselenium relationships in liver of Guiana dolphin: The possible role of Kupffer cells in the detoxification process by tiemannite formation. Plos One 2012, $7, \mathrm{n}^{\circ} \mathrm{e} 42162$.

(11) Sakamoto, M.; Itai, T.; Yasutake, A.; Iwasaki, T.; Yasunaga, G.; Fujise, Y.; Nakamura, M.; Murata, K.; Chan, H. M.; Domingo, J. L.; Marumoto, M. Mercury speciation and selenium in toothedwhale muscles. Environ. Res. 2015, 143, 55-61.

(12) Gajdosechova, Z.; Lawan, M. M.; Urgast, D. S.; Raab, A.; Scheckel, K. G.; Lombi, E.; Kopittke, P. M.; Loeschner, K.; Larsen, E. H.; Woods, G.; Brownlow, A.; Read, F. L.; Feldmann, J.; Krupp, E. M. In vivo formation of natural HgSe nanoparticles in the liver and brain of pilot whales. Sci. Rep. 2016, 6,34361 .

(13) Harris, H. H.; Pickering, I. J.; George, G. N. The chemical form of mercury in fish. Science 2003, $301,1203$.

(14) Kuwabara, J. S.; Arai, Y.; Topping, B. R.; Pickering, I. J.; George, G. N. Mercury speciation in piscivorous fish from mining-impacted reservoirs. Environ. Sci. Technol. 2007, 41, 2745-2749.

(15) Huggins, F. E.; Raverty, S. A.; Nielsen, O. S.; Sharp, N. E.; Robertson, J. D.; Ralston, N. V. C. An XAFS investigation of mercury and selenium in Beluga whale tissues. Environ. Bioindic. 2009, 4, 291-302.

(16) George, G. N.; MacDonald, T. C.; Korbas, M.; Singh, S. P.; Myers, G. J.; Watson, G. E.; O'Donoghue, J. L.; Pickering, I. J. The chemical forms of mercury and selenium in whale skeletal muscle. Metallomics 2011, 3, 1232-1237.

(17) Korbas, M.; O'Donoghue, J. L.; Watson, G. E.; Pickering, I. J.; Singh, S. P.; Myers, G. J.; Clarkson, T. W.; George, G. N. The chemical nature of mercury in human brain following poisoning or environmental exposure. ACS Chem. Neurosci. 2010, 1, 810-818. 
(18) MacDonald, T. C.; Korbas, M.; James, A. K.; Sylvain, N. J.; Hackett, M. J.; Nehzati, S.; Krone, P. H.; George, G. N.; Pickering, I. J. Interaction of mercury and selenium in the larval stage zebrafish vertebrate model. Metallomics 2015, 7, 1247-1255.

(19) Manceau, A.; Enescu, M.; Simionovici, A.; Lanson, M.; Gonzalez-Rey, M.; Rovezzi, M.; Tucoulou, R.; Glatzel, P.; Nagy, K. L.; Bourdineaud, J.-P. Chemical forms of mercury in human hair reveal sources of exposure. Environ. Sci. Technol. 2016, 50, 10721-10729.

(20) Thomas, S. A.; Gaillard, J. F. Cysteine addition promotes sulfide production and four-fold Hg(II)S coordination in actively metabolizing Escherichia coli. Environ. Sci. Technol. 2017, 51, 4642-4651.

(21) Thomas, S. A.; Rodby, K. E.; Roth, E. W.; Wu, J.; Gaillard, J. F. Spectroscopic and microscopic evidence of biomediated $\mathrm{HgS}$ species formation from $\mathrm{Hg}(\mathrm{II})$-cysteine complexes: Implications for Hg(II) bioavailability. Environ. Sci. Technol. 2018, 52, 10030-10039.

(22) Thomas, S. A.; Mishra, B.; Myneni, S. C. B. Cellular mercury coordination environment, and not cell surface ligands, influence bacterial methylmercury production. Environ. Sci. Technol. 2020, 54, 3960-3968.

(23) Pickering, I. J.; Cheng, Q.; Rengifo, E. M.; Nehzati, S.; Dolgova, N. V.; Kroll, T.; Sokaras, D.; George, G. N.; Arner, E. S. J. Direct observation of methylmercury and auranofin binding to selenocysteine in thioredoxin reductase. Inorg Chem. 2020, 59, 2711-2718.

(24) Bourdineaud, J. P.; Durn, G.; Režun, B.; Manceau, A.; Hrenović, J. The chemical species of mercury accumulated by Pseudomonas idrijaensis, a bacterium from a rock of the Idrija mercury mine, Slovenia. Chemosphere 2020, 248, $\mathrm{n}^{\circ} 126002$.

(25) Minet, A.; Manceau, A.; Valada-Mennuni, A.; Brault-Favrou, M.; Churlaud, C.; Fort, J.; Nguyen, T. C.; Spitz, J.; Bustamante, P.; Lacoue-Labarthe, T. Mercury in the tissues of five cephalopods species: first data on the nervous system Sci. Tot. Environ. 2021, 759, n 143907. 
(26) Manceau, A.; Nagy, K. L.; Glatzel, P.; Bourdineaud, J. P. Acute toxicity of divalent mercury to bacteria explained by the formation of dicysteinate and tetracysteinate complexes bound to proteins in Escherichia coli and Bacillus subtilis. Environ. Sci. Technol. 2021, 55, 3612-3623.

(27) Eiler, J. M.; Bergquist, B.; Bourg, I.; Cartigny, P.; Farquhar, J.; Gagnon, A.; Guo, W. F.; Halevy, I.; Hofmann, A.; Larson, T. E.; Levin, N.; Schauble, E. A.; Stolper, D. Frontiers of stable isotope geoscience. Chem. Geol. 2014, 372, 119-143.

(28) Sherman, L. S.; Blum, J. D.; Franzblau, A.; Basu, N. New insight into biomarkers of human mercury exposure using naturally occurring mercury stable isotopes. Environ. Sci. Technol. 2013, 47, 3403-3409.

(29) Li, M. L.; Sherman, L. S.; Blum, J. D.; Grandjean, P.; Mikkelsen, B.; Weihe, P.; Sunderland, E. M.; Shine, J. P. Assessing sources of human methylmercury exposure using stable mercury isotopes. Environ. Sci. Technol. 2014, 48, 8800-8806.

(30) Blum, J. D.; Sherman, L. S.; Johnson, M. W. Mercury isotopes in Earth and environmental sciences. In Annu. Rev. Earth Planet. Sci., Jeanloz, R., Ed. 2014; Vol. 42, pp 249-269.

(31) Wiederhold, J. G. Metal stable isotope signatures as tracers in environmental geochemistry. Environ. Sci. Technol. 2015, 2606-2624.

(32) Renedo, M.; Amouroux, D.; Duval, B.; Carravieri, A.; Tessier, E.; Barre, J.; Berail, S.; Pedrero, Z.; Cherel, Y.; Bustamante, P. Seabird tissues as efficient biomonitoring tools for $\mathrm{Hg}$ isotopic investigations: Implications of using blood and feathers from chicks and adults. Environ. Sci. Technol. 2018, 52, 4227-4234.

(33) Renedo, M.; Pedrero, Z.; Amouroux, D.; Cherel, Y.; Bustamante, P. Mercury isotopes of key tissues document mercury metabolic processes in seabirds. Chemosphere 2021, 263, $\mathrm{n}^{\circ} 127777$.

(34) Tsui, M. T. K.; Blum, J. D.; Kwon, S. Y. Review of stable mercury isotopes in ecology and biogeochemistry. Sci. Tot. Environ. 2020, 716. 
(35) Perrot, V.; Masbou, J.; Pastukhov, M. V.; Epov, V. N.; Point, D.; Berail, S.; Becker, P. R.; Sonke, J. E.; Amouroux, D. Natural Hg isotopic composition of different $\mathrm{Hg}$ compounds in mammal tissues as a proxy for in vivo breakdown of toxic methylmercury. Metallomics 2016, 8, 170-178.

(36) Li, M. L.; Juang, C. A.; Ewald, J. D.; Yin, R. S.; Mikkelsen, B.; Krabbenhoft, D. P.; Balcom, P. H.; Dassuncao, C.; Sunderland, E. M. Selenium and stable mercury isotopes provide new insights into mercury toxicokinetics in pilot whales. Sci. Tot. Environ. 2020, 710, n 136325.

(37) Poulin, B. A.; Janssen, S. E.; Rosera, T. J.; Krabbenhoft, D. P.; Eagles-Smith, C. A.; Ackerman, J. T.; Stewart, A. R.; Kim, E.; Baumann, Z.; Kim, J. H.; Manceau, A. Isotope fractionation from in vivo methylmercury detoxification in waterbirds. ACS Earth Space Chem. 2021, 5, 990-997.

(38) Bolea-Fernandez, E.; Rua-Ibarz, A.; Krupp, E. M.; Feldmann, J.; Kvanhaecke, F. High-precision isotopic analysis sheds new light on mercury metabolism in long-finned pilot whales (Globicephala melas). Sci. Rep. 2019, 9, $\mathrm{n}^{\circ} 7262$.

(39) Virieux, J.; Operto, S. An overview of full-waveform inversion in exploration geophysics. Geophysics 2009, 74, WCC1-WCC26.

(40) Rizzuti, G.; Gisolf, A. An iterative method for 2D inverse scattering problems by alternating reconstruction of medium properties and wavefields: theory and application to the inversion of elastic waveforms. Inverse Probl. 2017, 33.

(41) Tarantola, A. Inverse Problem Theory and Methods for Model Parameter Estimation. Society for Industrial and Applied Mathematics, Philadelphia: 2005; p 342.

(42) Calvetti, D.; Morigi, S.; Reichel, L.; Sgallari, F. Tikhonov regularization and the L-curve for large discrete ill-posed problems. J. Comput. Appl. Math. 2000, 123, 423-446.

(43) Manceau, A.; Brossier, R.; Poulin, B. A. Alternating inversion. GRICAD GitLab 2021, https://gricad-gitlab.univ-grenoble-alpes.fr/mercury_inversion/alternating_inversion. 
(44) Eagles-Smith, C. A.; Ackerman, J. T.; Yee, J.; Adelsbach, T. L. mercury demethylation in waterbird livers: dose-response thresholds and differences among species. Environ. Toxicol. Chem. 2009, $28,568-577$.

(45) Kaipio, J.; Somersalo, E. Statistical and computational inverse problems. . Springer.: New York, NY, 2010.

(46) Kwon, S. Y.; Blum, J. D.; Chirby, M. A.; Chesney, E. J. Application of mercury isotopes for tracing trophic transfer and internal distribution of mercury in marine fish feeding experiments. Environ. Toxicol. Chem. 2013, 32, 2322-2330.

(47) Achouba, A.; Dumas, P.; Ouellet, N.; Lemire, M.; Ayotte, P. Plasma levels of selenium-containing proteins in Inuit adults from Nunavik. Environ. Intern. 2016, 96, 8-15.

\section{FIGURE CAPTION}

Fig. 1. Relationship between $\delta^{202} \mathrm{Hg}$ and $f(\mathrm{MeHg})$ in long-finned pilot whales tissues. (a) Li et al. $(2020)^{36}$ data. (b) Bolea-Fernandez et al. $(2019)^{38}$ data. Filled and open data points are tissues from adult (A) and juvenile (J) pilot whales, respectively. Error bars present the associated error of measured $\delta^{202} \mathrm{Hg}$. In plot (a) the arrow identifies an outlier.

Fig. 2. Selection of long-finned pilot whales tissues giving the best linear regression between $\delta^{202} \mathrm{Hg}$ and $f(\mathrm{MeHg})$. (a) Li et al. $(2020)^{36}$ data. $\delta^{202} \mathrm{Hg}=-1.56+2.82 \times f(\mathrm{MeHg})\left(\mathrm{R}^{2}=0.96\right)$. (b) BoleaFernandez et al. $(2019)^{38}$ data. $\delta^{202} \mathrm{Hg}=-1.33+2.53 \times f(\mathrm{MeHg})\left(\mathrm{R}^{2}=0.97\right)$. Filled and open data points are tissues from adult (A) and juvenile (J) pilot whales, respectively. Error bars present the associated error of measured $\delta^{202} \mathrm{Hg}$. 
Fig. 3. Workflow of the alternating regularized inversion algorithm used to calculate ${ }^{202} \mathrm{Sp}_{i}$ from ${ }^{202} \mathrm{Hg}_{t}$ and $f(\mathrm{MeHg})$. Step 1: initialization of $\delta^{202} \mathrm{Sp}_{i}$ from the $\delta^{202} \mathrm{Hg}_{t}$ versus $f(\mathrm{MeHg})$ data. Step 2: regression analysis of $f\left(\mathrm{Hg}(\mathrm{Sec})_{4}\right)$ and $f(\mathrm{HgSe})$ with fixed $\delta^{202} \mathrm{Sp}_{i}$ values. Step 3: inversed calculation ${ }^{41}$ of $\delta^{202} \mathrm{Sp}_{i}$ with fixed $f\left(\mathrm{Hg}(\mathrm{Sec})_{4}\right)$ and $f(\mathrm{HgSe})$ values. Steps 2 and 3 are repeated with $f\left(\mathrm{Hg}(\mathrm{Sec})_{4}\right), f(\mathrm{HgSe}), \delta^{202} \mathrm{Sp}_{i}$ re-assigned new values at every iteration until convergence is reached.

Fig. 4. Proportions of the three $\mathrm{Hg}$ species $\left(f\left(\mathrm{Sp}_{i}\right)\right)$ in tissues of long-finned pilot whales as calculated with the alternating regularized inversion method. (a) Three-dimensional view of the ternary planes defined given by $f(\mathrm{MeHg}), f\left(\mathrm{Hg}(\mathrm{Sec})_{4}\right)$, and $f(\mathrm{HgSe})$ with $\delta^{202} \mathrm{Hg}_{t}$ as the third dimension. Cyan color refers to the Li et al. $(2020)^{36}$ data set and magenta color refers to the Bolea-Fernandez et al. $(2019)^{38}$ data set. (b) Two-dimensional projection of the two ternary planes.

Fig. 5. Proportions of the three $\mathrm{Hg}$ species (a) $f(\mathrm{MeHg})$, (b) $f\left(\mathrm{Hg}(\mathrm{Sec})_{4}\right)$, (c) $\left.f(\mathrm{HgSe})\right)$ as a function of the total $\mathrm{Hg}$ concentration $\left([\mathrm{Hg}]_{\mathrm{tot}}\right)$. Box plots of median and quartile ranges of the ratio of $(\mathrm{d})$ $f\left(\mathrm{Hg}(\mathrm{Sec})_{4}\right)$ to $f(\mathrm{MeHg})$ and (e) $f(\mathrm{HgSe})$ to $f(\mathrm{HgSec})_{4}$ for juvenile (open) and adult (filled) whale tissues. In plots (d) and $€$, error bars represent $10 \%$ and $90 \%$ percentiles and outliers are shown as data points.

Fig. 6. Stacked bar charts of the concentrations (dry weight, dw) of the three $\mathrm{Hg}$ species $\left(\mathrm{Sp}_{i}\right)$ in the heart (a), muscle (b), brain (c), kidneys (d), and liver (e) of long-finned pilot whales. Concentrations were determined using the proportions of $\mathrm{Hg}$ species $\left(f\left(\mathrm{Sp}_{i}\right)\right)$ determined by the alternating regularized inversion method and total $\mathrm{Hg}$ concentration published in Li et al. (2020) ${ }^{36}$ and Bolea-Fernandez et al. (2019). ${ }^{38}$ In each sub-plot, tissues are presented in ascending order of total $\mathrm{Hg}$ concentration and the vertical dashed line identifies the separation between juvenile and adult whales. The asterisk in plot $\mathrm{d}$ indicates a juvenile whale. 

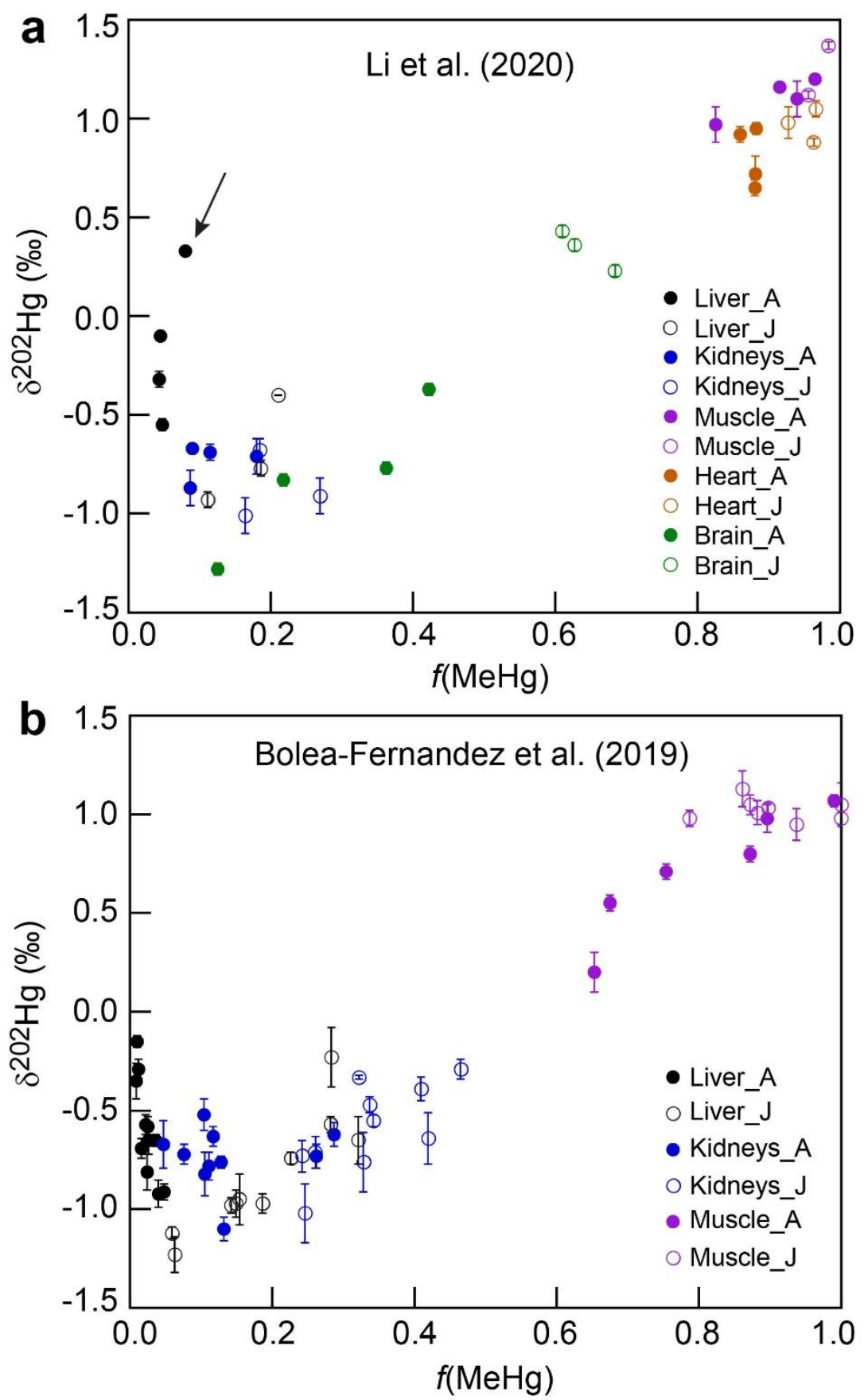

Figure 1 

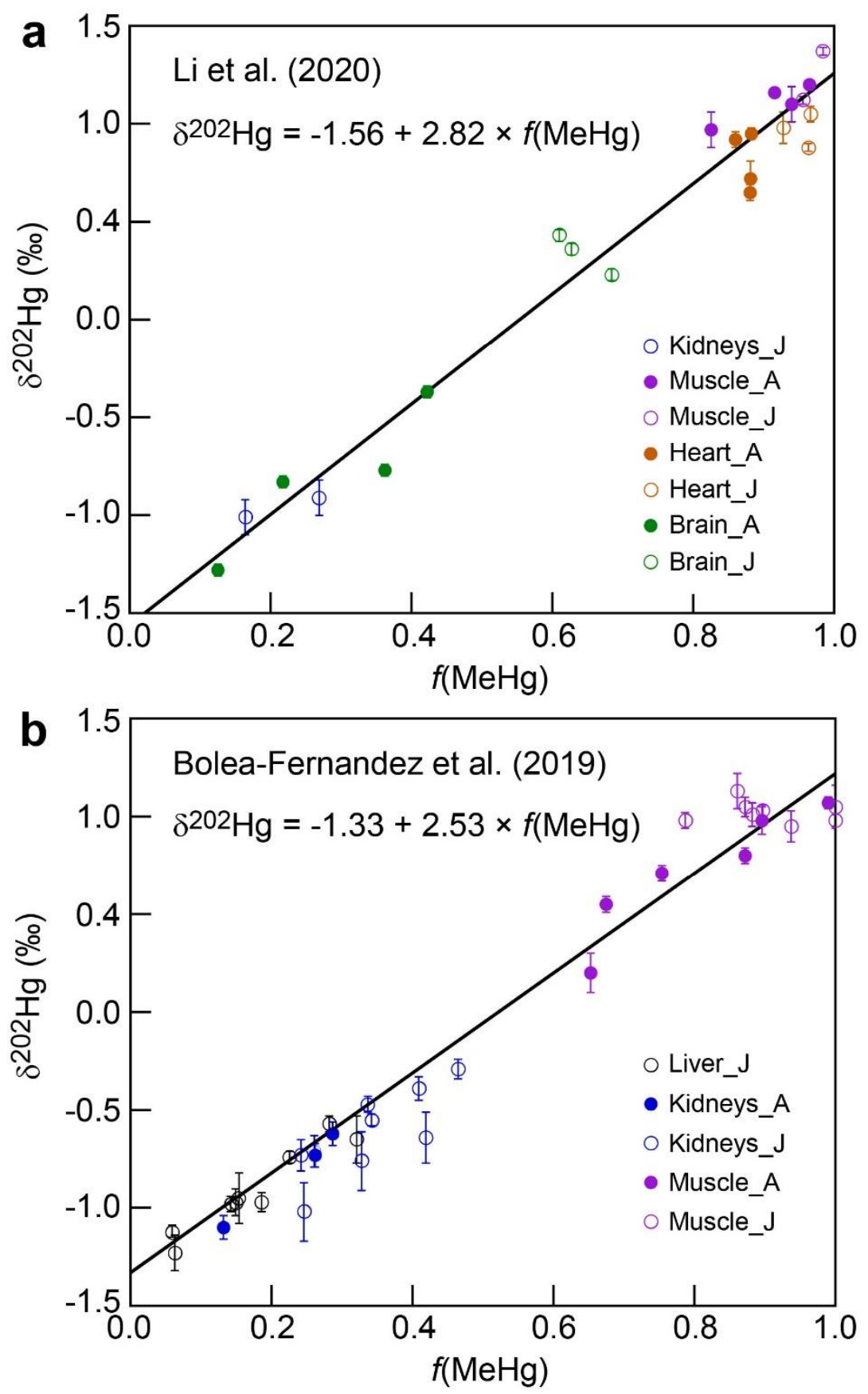

Figure 2 


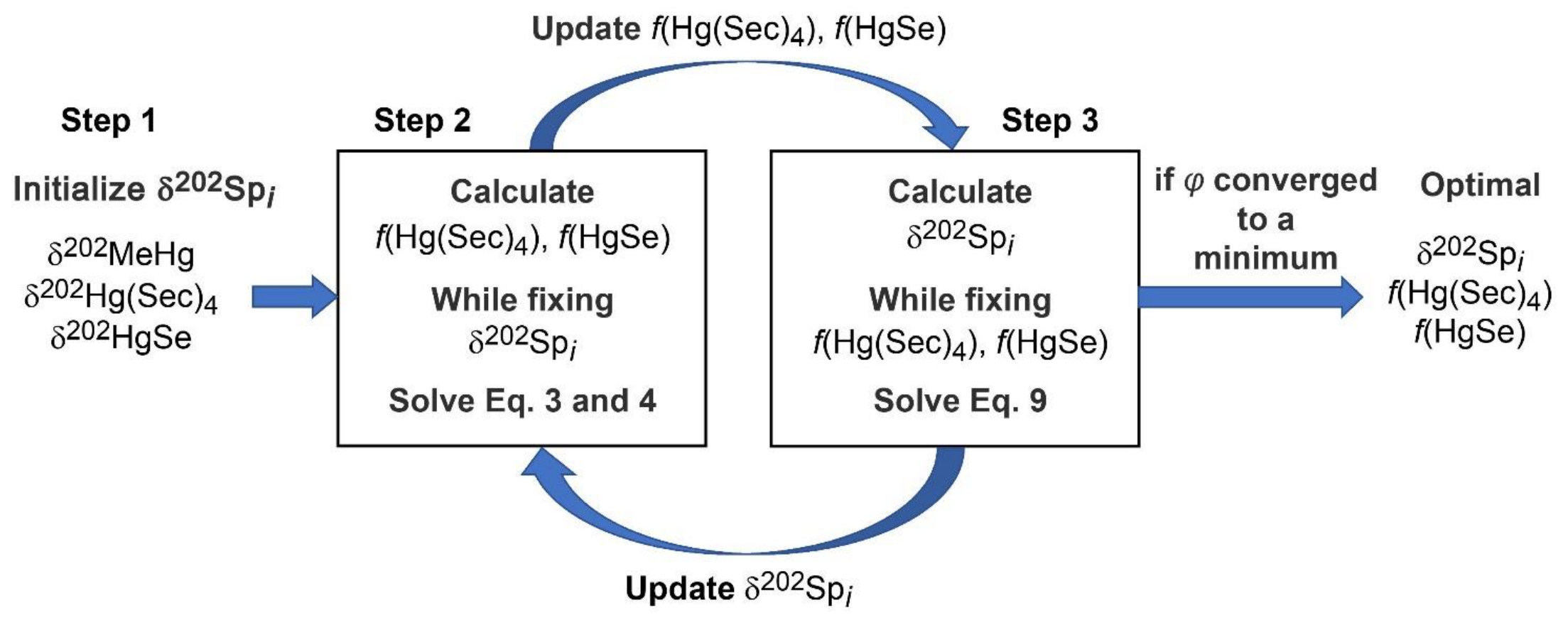

Figure 3 


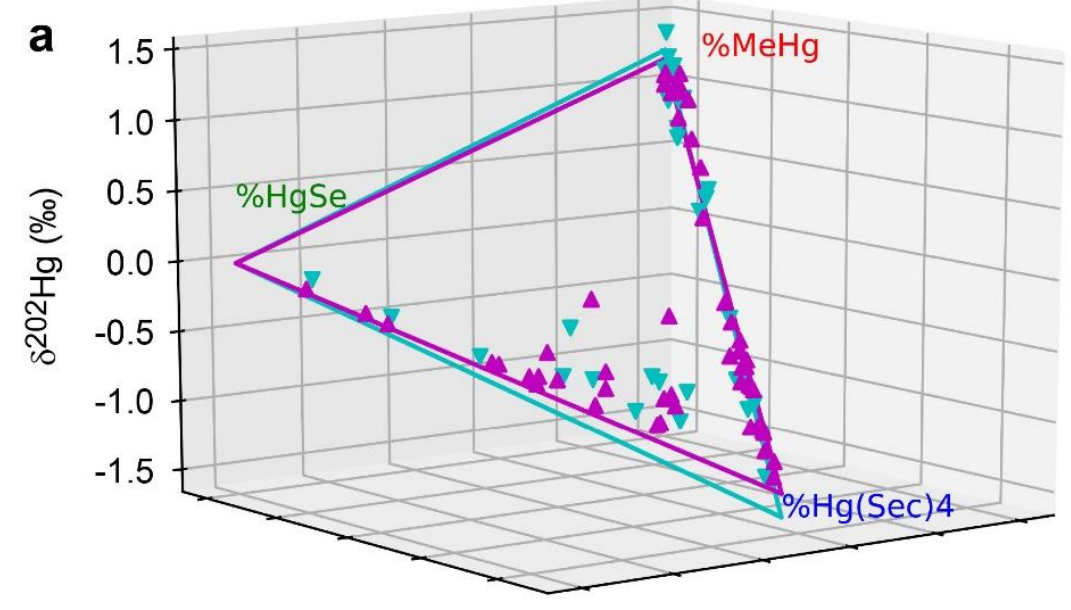

b

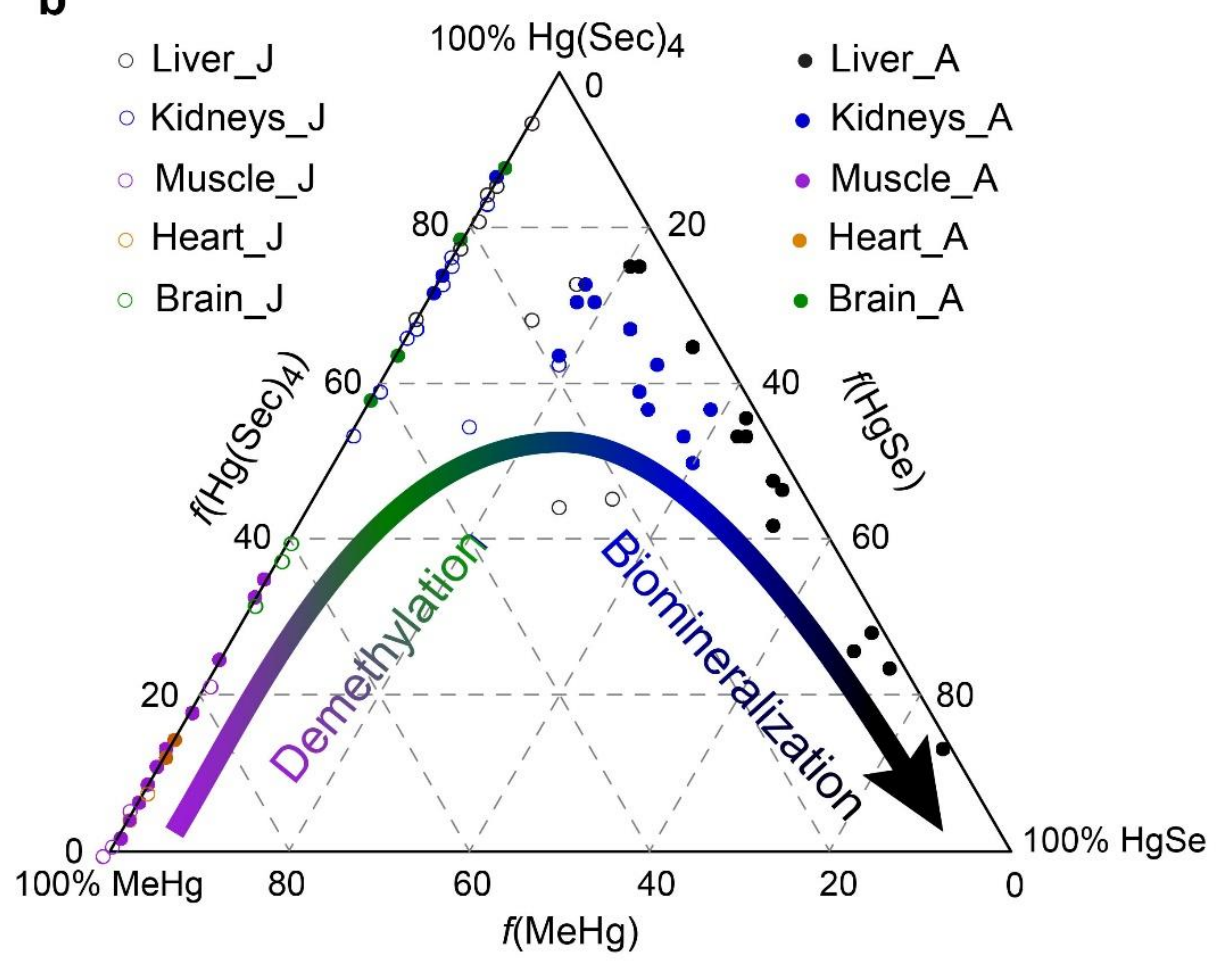

Figure 4 

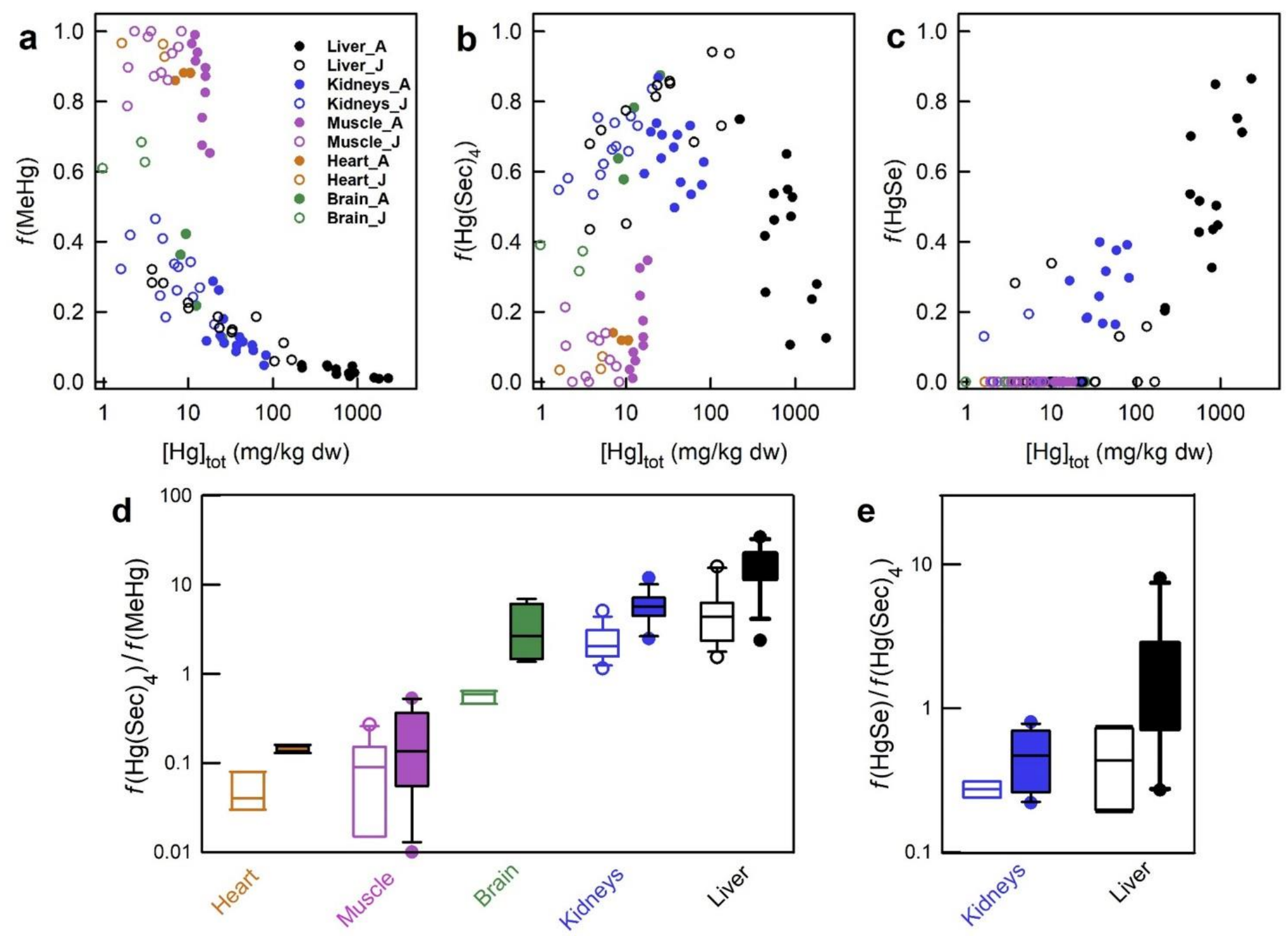

Figure 5 
$\mathrm{HgSe}$

$\mathrm{Hg}(\mathrm{Sec})_{4}$

$\mathrm{MeHg}$

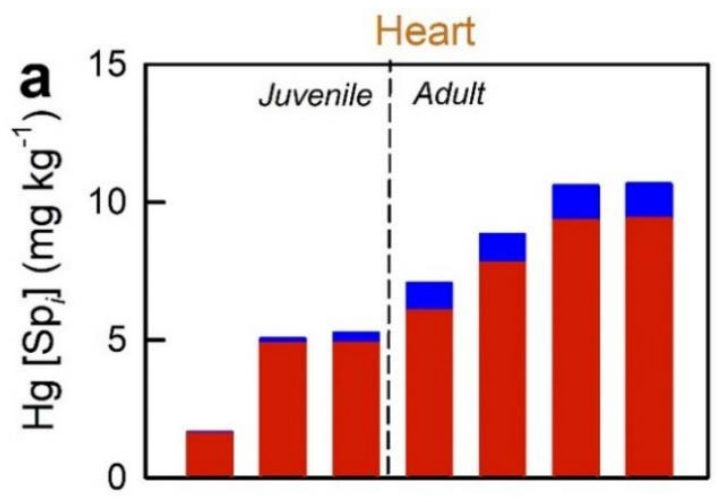

Muscle

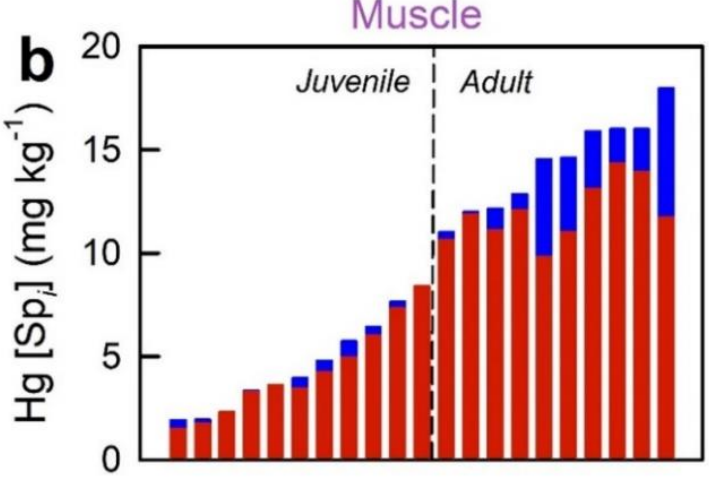

Kidneys

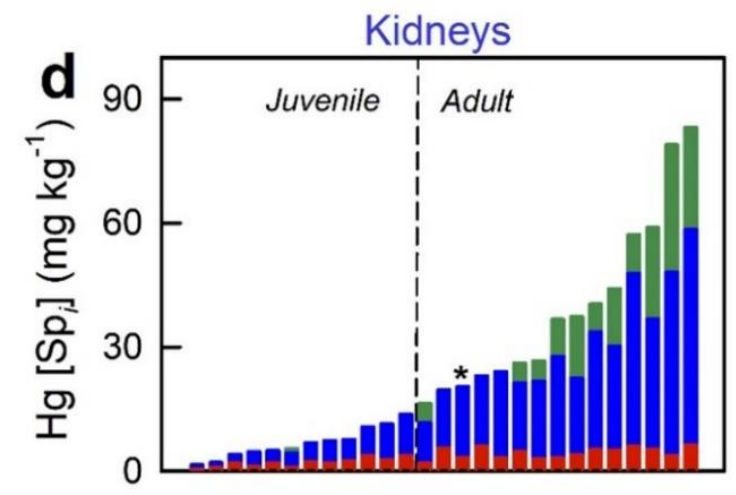

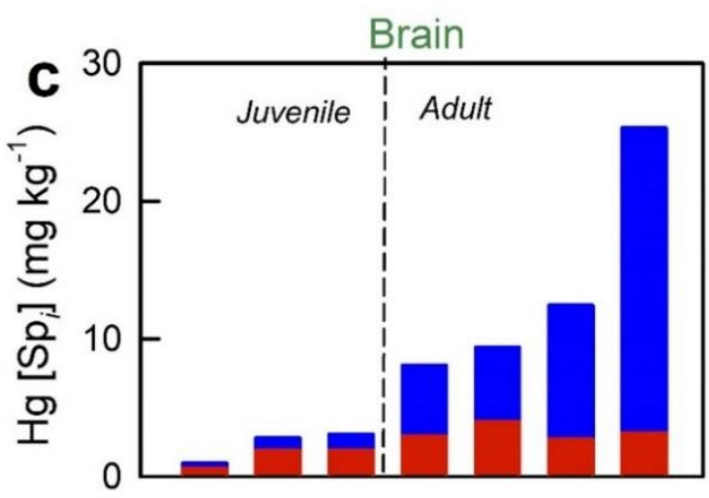

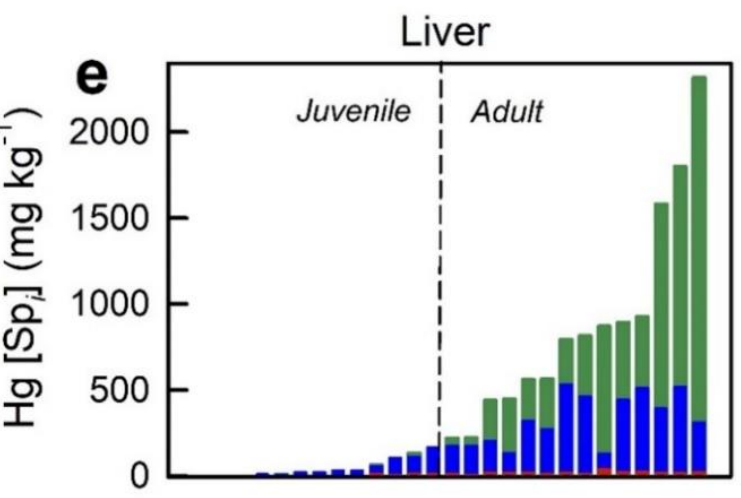

Figure 6 


\section{Supplementary Information}

Chemical Forms of Mercury in Pilot Whales Determined from Species-Averaged Mercury Isotope Signatures

Alain Manceau, ${ }^{1,{ }^{*}}$ Romain Brossier, ${ }^{1, *}$ and Brett A. Poulin ${ }^{2}$

${ }^{1}$ Université Grenoble Alpes, ISTerre, CNRS, 38000 Grenoble, France

${ }^{2}$ Department of Environmental Toxicology, University of California Davis, Davis, CA 95616, USA

\section{Supplementary Figures}
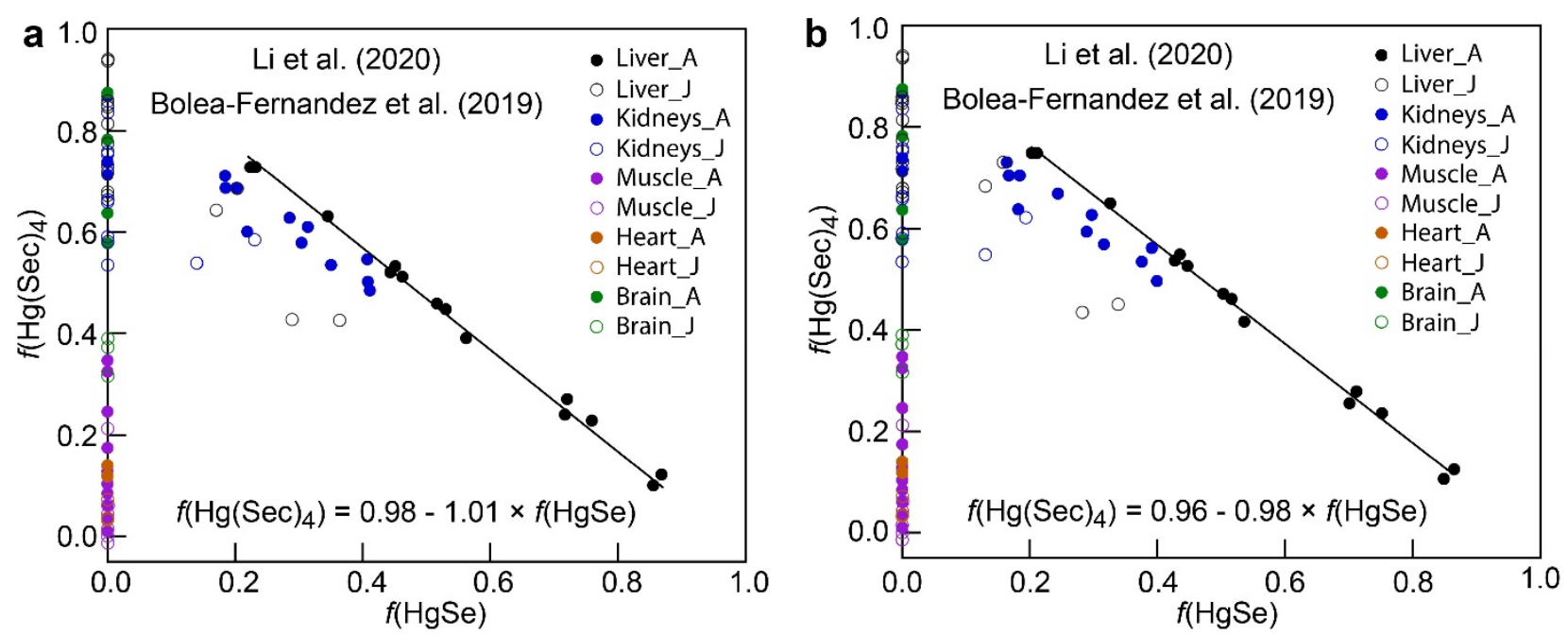

Figure S1. Relationship between $f\left(\mathrm{Hg}(\mathrm{Sec})_{4}\right)$ and $f(\mathrm{HgSe})$ estimated from the regression analysis (a) and calculated from the alternating regularized inversion method (b) using the $\delta^{\mathbf{2 0 2}} \mathbf{H g}_{t}$ versus $\boldsymbol{f}$ (MeHg) data (Fig. 2) of $\mathrm{Li}$ et al. ${ }^{1}$ and Bolea-Fernandez et al. ${ }^{2}$. In plot a, $\delta^{202} \mathrm{MeHg}=1.26 \%$, $\delta^{202} \mathrm{Hg}(\mathrm{Sec})_{4}=-1.56 \%$, $\delta^{202} \mathrm{HgSe}=0.00 \%$ o for the Li et al. ${ }^{1}$ data, and $\delta^{202} \mathrm{MeHg}=1.20 \%, \delta^{202} \mathrm{Hg}(\mathrm{Sec}) 4$ $=-1.33 \%$ o, $\delta^{202} \mathrm{HgSe}=0.00 \%$ or the Bolea-Fernandez et al. ${ }^{2}$ data. In plot b, $\delta^{202} \mathrm{MeHg}=1.23 \%$, $\delta^{202} \mathrm{Hg}(\mathrm{Sec})_{4}=-1.46 \%$, $\delta^{202} \mathrm{HgSe}=0.00 \%$ for the Li et al. ${ }^{1}$ data, and $\delta^{202} \mathrm{MeHg}=1.17 \%, \delta^{202} \mathrm{Hg}(\mathrm{Sec})_{4}$ $=-1.29 \%$, $\delta^{202} \mathrm{HgSe}=0.00 \%$ for the Bolea-Fernandez et al. ${ }^{2}$ data. 

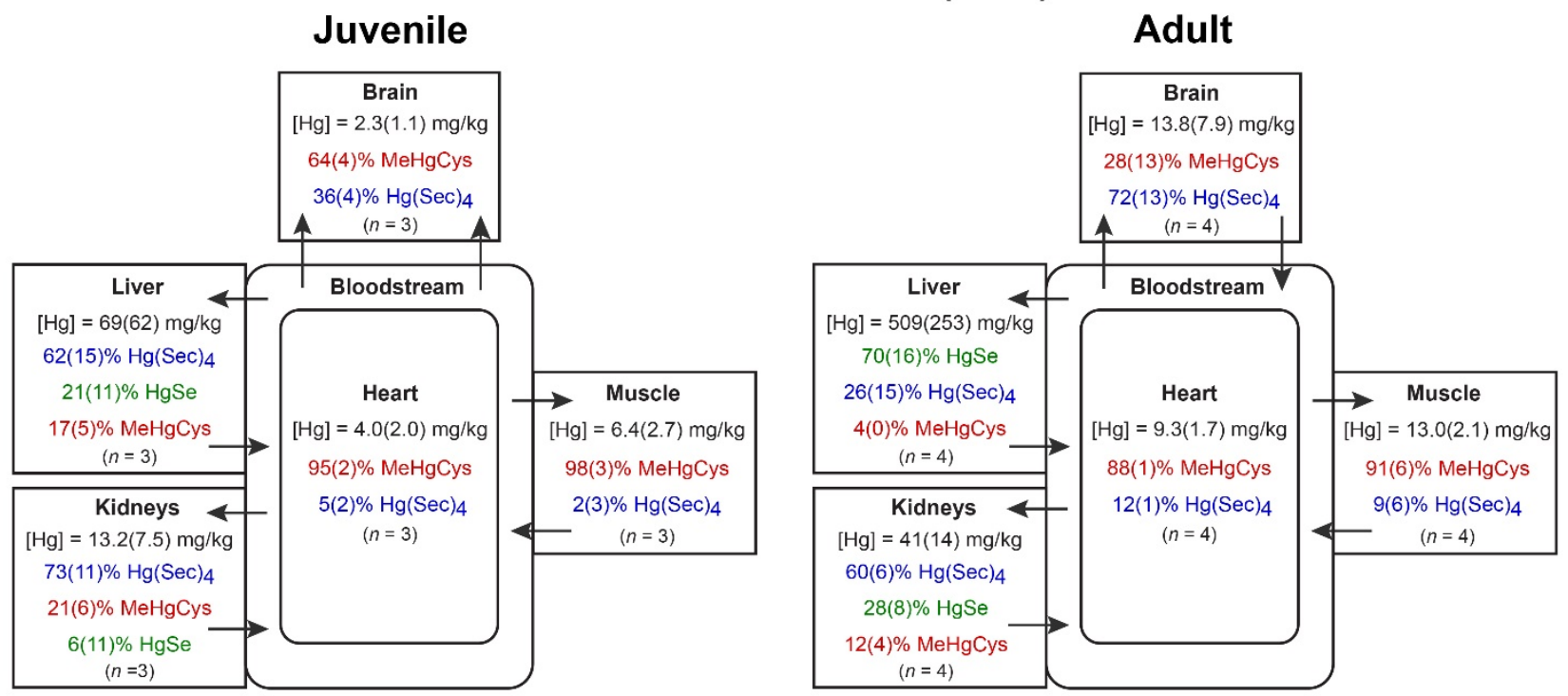

b

Pilot whales - Bolea-Fernandez et al. (2019) Juvenile
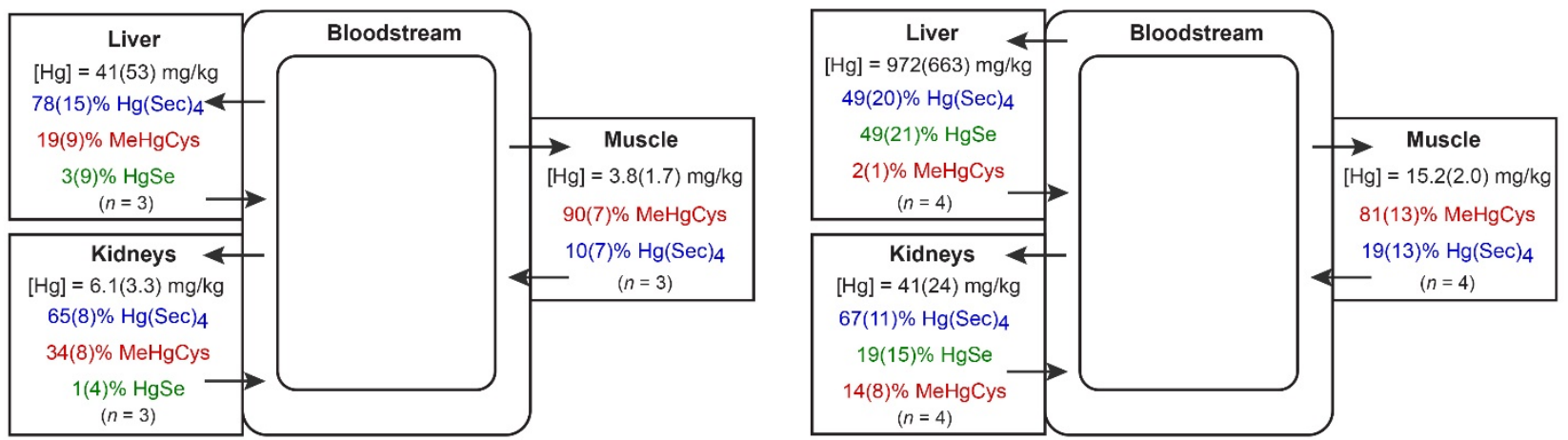

C

Giant petrel - Manceau et al. (2021)
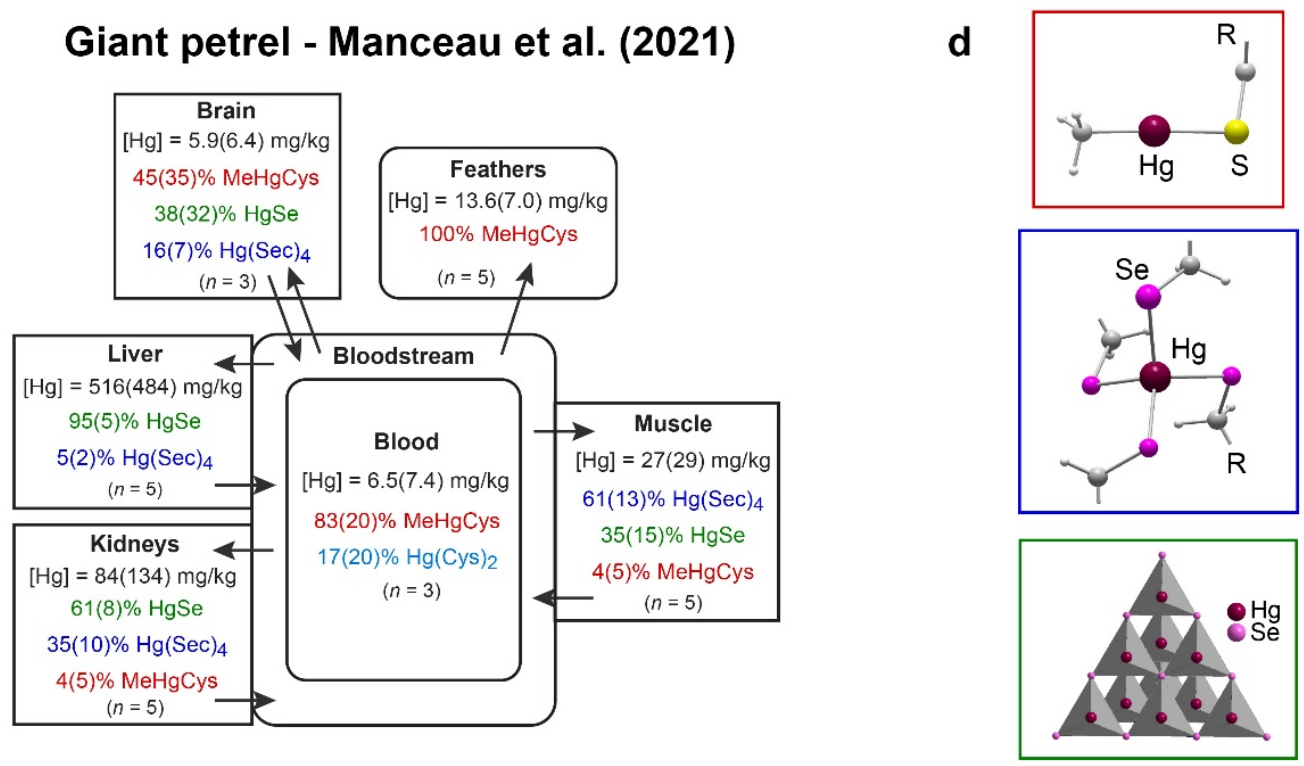
Figure S2. Diagrammatic pictures of the average concentration (dry weight, dw) and speciation of $\mathrm{Hg}$ in tissues of long-finned pilot whales and giant petrel. a $\mathrm{Li}$ et al. ${ }^{1}$ data. $\mathbf{b}$ Bolea-Fernandez et al. ${ }^{2}$ data. c Manceau et al. ${ }^{3}$ data. Cys and Sec stand for cysteine and selenocysteine residues within a polymeric chain of peptide or protein, not for free amino acids. The numbers in parentheses are the standard deviations, and $n$ is the number of individuals. d Ball-and-stick representations of the linear coordination of $\mathrm{Hg}$ in $\mathrm{MeHgCys}$ and its four-fold coordination to selenocysteine in $\mathrm{Hg}(\mathrm{Sec}) 4$, and portion of the HgSe structure. Dark red, purple, yellow, gray, and light gray spheres represent $\mathrm{Hg}$, Se, $\mathrm{S}, \mathrm{C}$, and $\mathrm{H}$, respectively.

\section{Supplementary Tables}

Table S1. Total $\mathrm{Hg}$ concentration ([Hg]tot) and $\mathrm{Hg}$ isotopic composition measured by Li et al. ${ }^{1}$, the $\% \mathrm{MeHg}, \% \mathrm{Hg}(\mathrm{Sec}) 4$, and $\% \mathrm{HgSe}$ calculated by alternated regularized inversion, and the effective $\mathrm{Hg}: \mathrm{Se}\left(\mathrm{Hg}: \mathrm{Se}_{\mathrm{eff}}\right)$.

\begin{tabular}{|c|c|c|c|c|c|c|c|c|}
\hline Age & Tissue & $\begin{array}{c}{[\mathrm{Hg}]_{\text {tot }}} \\
\mathbf{d w}(\mathrm{ppm})\end{array}$ & $\delta^{202} \mathrm{Hg}(\%)$ & Std & \%МeHg & $\% \mathrm{Hg}(\mathrm{Sec}) 4^{\mathrm{a}}$ & $\% \mathrm{HgSe}^{\mathrm{a}}$ & $\mathrm{Hg} / \mathrm{Se}_{\text {eff }}$ \\
\hline Juvenile & Brain & 3.1 & 0.36 & 0.03 & 62.7 & 37.3 & 0.0 & 0.30 \\
\hline Juvenile & Brain & 1.0 & 0.43 & 0.03 & 61.0 & 39.0 & 0.0 & 0.06 \\
\hline Juvenile & Brain & 2.8 & 0.23 & 0.03 & 68.4 & 31.6 & 0.0 & 0.23 \\
\hline Adult & Brain & 9.4 & -0.37 & 0.03 & 42.2 & 57.8 & 0.0 & 1.05 \\
\hline Adult & Brain & 25.3 & -1.28 & 0.03 & 12.5 & 87.5 & 0.0 & 3.06 \\
\hline Adult & Brain & 12.4 & -0.83 & 0.03 & 21.8 & 78.2 & 0.0 & 1.93 \\
\hline Adult & Brain & 8.1 & -0.77 & 0.03 & 36.3 & 63.7 & 0.0 & 1.06 \\
\hline Juvenile & Heart & 5.3 & 0.98 & 0.08 & 92.8 & 7.2 & 0.0 & 0.05 \\
\hline Juvenile & Heart & 1.6 & 1.05 & 0.04 & 96.6 & 3.4 & 0.0 & 0.00 \\
\hline Juvenile & Heart & 5.0 & 0.88 & 0.02 & 96.3 & 3.7 & 0.0 & 0.02 \\
\hline Adult & Heart & 10.6 & 0.95 & 0.03 & 88.2 & 11.8 & 0.0 & 0.12 \\
\hline Adult & Heart & 10.7 & 0.65 & 0.04 & 88.1 & 12.0 & 0.0 & 0.15 \\
\hline Adult & Heart & 8.8 & 0.72 & 0.09 & 88.1 & 11.9 & 0.0 & 0.11 \\
\hline Adult & Heart & 7.1 & 0.92 & 0.04 & 86.0 & 14.0 & 0.0 & 0.10 \\
\hline Juvenile & Muscle & 8.3 & 1.08 & 0.09 & 101.4 & -1.4 & 0.0 & 0.00 \\
\hline Juvenile & Muscle & 3.3 & 1.37 & 0.02 & 98.4 & 1.6 & 0.0 & 0.01 \\
\hline Juvenile & Muscle & 7.7 & 1.12 & 0.02 & 95.6 & 4.4 & 0.0 & 0.17 \\
\hline Adult & Muscle & 12.9 & 1.10 & 0.09 & 94.0 & 6.0 & 0.0 & 0.28 \\
\hline Adult & Muscle & 15.9 & 0.97 & 0.09 & 82.5 & 17.5 & 0.0 & 1.00 \\
\hline Adult & Muscle & 12.2 & 1.16 & 0.02 & 91.5 & 8.5 & 0.0 & 0.35 \\
\hline Adult & Muscle & 11.0 & 1.20 & 0.02 & 96.5 & 3.5 & 0.0 & 0.11 \\
\hline Juvenile & Kidney & 20.4 & -1.01 & 0.09 & 16.4 & 83.6 & 0.0 & 0.74 \\
\hline Juvenile & Kidney & 5.4 & -0.68 & 0.06 & 18.5 & 62.1 & 19.4 & 0.21 \\
\hline Juvenile & Kidney & 13.7 & -0.91 & 0.09 & 26.9 & 73.1 & 0.0 & 0.48 \\
\hline Adult & Kidney & 26.1 & -0.71 & 0.09 & 18.0 & 63.8 & 18.2 & 0.82 \\
\hline Adult & Kidney & 58.9 & -0.67 & 0.02 & 9.0 & 53.5 & 37.5 & 1.03 \\
\hline Adult & Kidney & 36.7 & -0.87 & 0.09 & 8.7 & 66.9 & 24.4 & 1.01 \\
\hline Adult & Kidney & 44.1 & -0.69 & 0.04 & 11.5 & 56.9 & 31.6 & 0.71 \\
\hline Juvenile & Liver & 134.3 & -0.93 & 0.04 & 11.1 & 73.1 & 15.8 & 2.00 \\
\hline
\end{tabular}




\begin{tabular}{llccccccc} 
Juvenile & Liver & 10.1 & -0.40 & 0 & 21.0 & 45.1 & 33.8 & 0.70 \\
Juvenile & Liver & 63.7 & -0.77 & 0.04 & 18.6 & 68.4 & 13.0 & 1.74 \\
Adult & Liver & 439.0 & -0.55 & 0.03 & 4.7 & 41.7 & 53.6 & 1.42 \\
Adult & Liver & 870.8 & -0.10 & 0 & 4.5 & 10.6 & 84.9 & 1.20 \\
Adult & Liver & 446.0 & -0.32 & 0.04 & 4.3 & 25.6 & 70.1 & 1.42 \\
Adult & Liver & 281.3 & 0.33 & 0 & 8.0 & -15.8 & 107.8 & -- \\
\hline
\end{tabular}

${ }^{a}$ Values obtained with $\lambda=0.01$. A difference of $5.4 \pm 1.0 \%$ is obtained with a regularization $\lambda$ value of $5 \times 10^{-4}$ optimized on the giant petrel isotopic and spectroscopic data (Manceau et al., submitted).

Table S2. Total Hg concentration ([Hg $]_{\text {tot }}$ ) and $\mathrm{Hg}$ isotopic composition measured by Bolea-Fernandez et al. ${ }^{2}$, the $\% \mathrm{MeHg}, \% \mathrm{Hg}(\mathrm{Sec}) 4$, and $\% \mathrm{HgSe}$ calculated by alternated regularized inversion, and the effective $\mathrm{Hg}: \mathrm{Se}(\mathrm{Hg}: \mathrm{Se}$ eff).

\begin{tabular}{|c|c|c|c|c|c|c|c|c|}
\hline Age & Tissue & $\begin{array}{c}{[\mathrm{Hg}]_{\text {tot }}} \\
\mathrm{dw}(\mathrm{ppm})\end{array}$ & $\delta^{202} \mathrm{Hg}(\%)$ & Std & \%МeHg & $\% \mathrm{Hg}(\mathrm{Sec})_{4^{\mathrm{a}}}$ & $\% \mathrm{HgSe}^{\mathrm{a}}$ & $\mathrm{Hg} / \mathrm{Se}_{\text {eff }}$ \\
\hline Juvenile & Liver & 3.7 & -0.65 & 0.12 & 32.1 & 67.9 & 0.0 & 0.26 \\
\hline Juvenile & Liver & 5.1 & -0.57 & 0.04 & 28.2 & 71.8 & 0.0 & 0.68 \\
\hline Juvenile & Liver & 3.7 & -0.23 & 0.15 & 28.3 & 43.5 & 28.2 & 0.33 \\
\hline Juvenile & Liver & 9.9 & -0.74 & 0.03 & 22.6 & 77.4 & 0.0 & 0.82 \\
\hline Juvenile & Liver & 23.4 & -0.95 & 0.13 & 15.4 & 84.6 & 0.0 & 0.88 \\
\hline Juvenile & Liver & 22.5 & -0.97 & 0.05 & 18.6 & 81.4 & 0.0 & 1.31 \\
\hline Juvenile & Liver & 33.2 & -0.97 & 0.07 & 14.9 & 85.1 & 0.0 & 1.66 \\
\hline Juvenile & Liver & 104.4 & -1.12 & 0.03 & 5.9 & 94.1 & 0.0 & 2.43 \\
\hline Juvenile & Liver & 32.8 & -0.98 & 0.04 & 14.2 & 85.8 & 0.0 & 1.81 \\
\hline Juvenile & Liver & 167.3 & -1.23 & 0.09 & 6.3 & 93.7 & 0.0 & 2.80 \\
\hline Adult & Liver & 219.9 & -0.91 & 0.04 & 4.8 & 74.9 & 20.3 & 1.97 \\
\hline Adult & Liver & 221.8 & -0.92 & 0.07 & 4.0 & 74.9 & 21.1 & 2.31 \\
\hline Adult & Liver & 815.5 & -0.69 & 0.05 & 1.6 & 54.9 & 43.5 & 1.87 \\
\hline Adult & Liver & 560.2 & -0.65 & 0.03 & 3.6 & 53.7 & 42.7 & 1.91 \\
\hline Adult & Liver & 564.0 & -0.57 & 0.05 & 2.2 & 46.2 & 51.6 & 1.82 \\
\hline Adult & Liver & 926.1 & -0.65 & 0.07 & 2.6 & 52.7 & 44.7 & 2.10 \\
\hline Adult & Liver & 792.7 & -0.81 & 0.09 & 2.4 & 65.0 & 32.6 & 2.30 \\
\hline Adult & Liver & 891.8 & -0.58 & 0.05 & 2.5 & 47.2 & 50.3 & 1.80 \\
\hline Adult & Liver & 1798.8 & -0.35 & 0.09 & 0.9 & 27.9 & 71.2 & 1.60 \\
\hline Adult & Liver & 1581.6 & -0.29 & 0.05 & 1.2 & 23.6 & 75.2 & 1.36 \\
\hline Adult & Liver & 2317.1 & -0.15 & 0.03 & 1.0 & 12.5 & 86.5 & 1.71 \\
\hline Juvenile & Kidneys & 7.6 & -0.76 & 0.15 & 32.8 & 67.2 & 0.0 & -- \\
\hline Juvenile & Kidneys & 2.1 & -0.64 & 0.13 & 41.9 & 58.1 & 0.0 & -- \\
\hline Juvenile & Kidneys & 1.6 & -0.33 & 0.01 & 32.2 & 54.8 & 13.0 & -- \\
\hline Juvenile & Kidneys & 4.6 & -1.02 & 0.15 & 24.6 & 75.4 & 0.0 & -- \\
\hline Juvenile & Kidneys & 4.1 & -0.29 & 0.05 & 46.5 & 53.5 & 0.0 & -- \\
\hline Juvenile & Kidneys & 7.4 & -0.71 & 0.08 & 26.1 & 73.9 & 0.0 & -- \\
\hline Juvenile & Kidneys & 5.0 & -0.39 & 0.06 & 40.9 & 59.1 & 0.0 & -- \\
\hline Juvenile & Kidneys & 6.9 & -0.47 & 0.04 & 33.7 & 66.3 & 0.0 & -- \\
\hline Juvenile & Kidneys & 11.4 & -0.73 & 0.08 & 24.2 & 75.8 & 0.0 & -- \\
\hline Juvenile & Kidneys & 10.7 & -0.55 & 0.03 & 34.2 & 65.8 & 0.0 & -- \\
\hline Adult & Kidneys & 24.0 & -1.10 & 0.06 & 13.2 & 86.8 & 0.0 & -- \\
\hline
\end{tabular}




\begin{tabular}{|c|c|c|c|c|c|c|c|c|}
\hline Adult & Kidneys & 23.0 & -0.73 & 0.06 & 26.2 & 73.8 & 0.0 & -- \\
\hline Adult & Kidneys & 26.7 & -0.78 & 0.07 & 11.1 & 70.5 & 18.4 & -- \\
\hline Adult & Kidneys & 19.6 & -0.62 & 0.06 & 28.7 & 71.3 & 0.0 & -- \\
\hline Adult & Kidneys & 37.3 & -0.52 & 0.08 & 10.4 & 49.7 & 39.9 & -- \\
\hline Adult & Kidneys & 57.2 & -0.82 & 0.11 & 10.5 & 73.1 & 16.4 & -- \\
\hline Adult & Kidneys & 16.4 & -0.63 & 0.05 & 11.7 & 59.4 & 28.9 & -- \\
\hline Adult & Kidneys & 40.4 & -0.76 & 0.03 & 12.8 & 70.5 & 16.7 & -- \\
\hline Adult & Kidneys & 78.9 & -0.67 & 0.12 & 4.7 & 56.2 & 39.1 & -- \\
\hline Adult & Kidneys & 83.1 & -0.72 & 0.05 & 7.6 & 62.7 & 29.7 & -- \\
\hline Juvenile & Muscle & 1.9 & 1.03 & 0.03 & 89.7 & 10.3 & 0.0 & -- \\
\hline Juvenile & Muscle & 2.3 & 1.05 & 0.11 & 100 & 0.0 & 0.0 & -- \\
\hline Juvenile & Muscle & 1.9 & 0.98 & 0.04 & 78.7 & 21.3 & 0.0 & -- \\
\hline Juvenile & Muscle & 4.0 & 1.05 & 0.05 & 87.2 & 12.8 & 0.0 & -- \\
\hline Juvenile & Muscle & 3.6 & 0.98 & 0.03 & 100 & 0.0 & 0.0 & -- \\
\hline Juvenile & Muscle & 5.8 & 1.13 & 0.09 & 86.1 & 13.9 & 0.0 & -- \\
\hline Juvenile & Muscle & 4.8 & 1.01 & 0.06 & 88.2 & 11.8 & 0.0 & -- \\
\hline Juvenile & Muscle & 6.4 & 0.95 & 0.08 & 93.7 & 6.3 & 0.0 & -- \\
\hline Adult & Muscle & 12.0 & 1.07 & 0.03 & 99.0 & 1.0 & 0.0 & -- \\
\hline Adult & Muscle & 16.0 & 0.98 & 0.07 & 89.6 & 10.4 & 0.0 & -- \\
\hline Adult & Muscle & 16.0 & 0.80 & 0.04 & 87.2 & 12.8 & 0.0 & -- \\
\hline Adult & Muscle & 14.6 & 0.71 & 0.04 & 75.4 & 24.6 & 0.0 & -- \\
\hline Adult & Muscle & 14.6 & 0.55 & 0.04 & 67.5 & 32.5 & 0.0 & -- \\
\hline Adult & Muscle & 18.0 & 0.20 & 0.10 & 65.3 & 34.7 & 0.0 & -- \\
\hline
\end{tabular}

${ }^{a}$ Values obtained with $\lambda=0.01$. A difference of $3.0 \pm 0.4 \%$ is obtained with a regularization $\lambda$ value of $5 \times 10^{-4}$ optimized on the giant petrel spectroscopic and isotopic data (Manceau et al., submitted).

\section{Supplementary references}

(1) Li, M. L.; Juang, C. A.; Ewald, J. D.; Yin, R. S.; Mikkelsen, B.; Krabbenhoft, D. P.; Balcom, P. H.; Dassuncao, C.; Sunderland, E. M. Selenium and stable mercury isotopes provide new insights into mercury toxicokinetics in pilot whales. Sci. Tot. Environ. 2020, 710, n 136325.

(2) Bolea-Fernandez, E.; Rua-Ibarz, A.; Krupp, E. M.; Feldmann, J.; Kvanhaecke, F. High-precision isotopic analysis sheds new light on mercury metabolism in long-finned pilot whales (Globicephala melas). Sci. Rep. 2019, 9, n 7262.

(3) Manceau, A.; Gaillot, A. C.; Glatzel, P.; Cherel, Y.; Bustamante, P. In vivo formation of HgSe nanoparticles and Hg-tetraselenolate complex from methylmercury in seabird - Implications for the Hg-Se antagonism. Environ. Sci. Technol. 2021, 55, 1515-1526. 